\title{
Thermal potential of a geothermal earth-to-air heat exchanger in six climatic conditions of México
}

\author{
M. Rodríguez-Vázquez ${ }^{1}$, J. Xamán ${ }^{1, *}$, Y. Chávez ${ }^{1}$, I. Hernández-Pérez ${ }^{2}$, and E. Simá ${ }^{1}$ \\ 1 Tecnológico Nacional de México/CENIDET, Prol. Av. Palmira s/n. Col. Palmira. Cuernavaca, Morelos 62490, Mexico \\ ${ }^{2}$ Universidad Juárez Autónoma de Tabasco, UJAT, División Académica de Ingeniería y Arquitectura, Carretera \\ Cunduacán-Jalpa de Méndez km. 1, Cunduacán, Tabasco 86690, Mexico
}

Received: 6 February 2019 / Accepted: 9 February 2020

\begin{abstract}
In this paper, the thermal and ventilation potential of a geothermal Earth-to-Air Heat exchanger (EAHE) is studied for six weather in Mexico. The cities for the study and their climate were Villahermosa (hothumid), Merida (hot-sub humid), Monterrey (dry), Juarez City (very dry), Zacualtipan-Hidalgo (warm-humid) and Mexico City (warm-sub-humid). The thermal behavior of the EAHE was modeled numerically for the corresponding warmest and coldest days of the year for each city and three values of Reynolds number. The $24 \mathrm{hrs}$ simulations were carried out with an in-house code using data every 10 minutes. To get the results, 5,184 computational runs were necessary. The results showed that the EAHE has poor ventilation potential for climates with high levels of humidity such as Villahermosa, while for cities with low levels of humidity such as Chihuahua, the ventilation potential increases significantly, the rest of the cities fall in between. As for its application in Mexico, the results show that the EAHE is highly recommended for dry climates such as at the north of the country and not recommended for humid climates such as at the south and south-east of the country.
\end{abstract}

Keywords: earth-to-air heat exchanger / thermal potential / passive cooling system

\section{Introduction}

Nowadays, society has developed a huge dependence on electricity to carry out his daily activities; most of this electricity is produced by burning fossil fuels. The accelerated growing of population has exacerbated the electricity consumption and the greenhouse gases produced from these fuels has contributed to one of the major problems human kind is facing at the present time known as climate change. This situation has forced people use mechanical devices to achieve thermal comfort inside the buildings, which in turn, demand electricity for functioning, becoming this situation a vicious circle. However, there are many alternatives to achieve or get closer at least, to the comfort temperature inside a building without the use of mechanical devices; one of these alternatives is the earthto-air heat exchanger (EAHE).

An EAHE is a system that consists of one or a series of tubes buried at a certain depth with the aim to heat or cool an airflow. This is achieved by taking advantage of the

\footnotetext{
* e-mail: jxaman@cenidet.edu.mx
}

thermal inertia of the ground, which due to its thermophysical properties can have a higher or lower temperature compared to the environment.

The heating and cooling capacity of the EAHE varies depending on different factors such as the climate, type of soil, and the design parameters. This capacity has been studied both experimentally $[1-4]$ and theoretically (analytical and /or numerical) or a combination of both methods.

Among the theoretical studies we can find a great diversity of works like [5-9] the vast majority evaluate the thermal performance of the EAHE under diverse climatic conditions and design parameters. Analytical studies are generally considered to model the thermal behavior of the EAHE, assumptions such as: (i) steady state, (ii) thermophysical properties and temperature of the soil temperature are constant, (iii) cylindrical coordinates, (iv) one-dimensional heat transfer. Although many of these assumptions facilitate EAHE modeling, they also limit the ability to model, or neglect certain aspects of the functioning of the system. Reference [10] developed an analytical model that, in addition to the considerations mentioned above, they consider boundary conditions and the variation of soil and air temperature as a function of time. 
The numerical studies on the other hand, implement computational fluid dynamics (volume, element or finite differences), where they model the convection-conduction heat transfer in two or three dimensions. Among the considerations commonly made in this type of studies are: (i) steady state, (ii) turbulent regime, (iii) constant soil properties, (iv) constant and uniform air velocity. The more considerations a numerical model has, the greater capacity it will have to represent the reality of the system, however, this will increase its cost of computational resources. These numerical models reproduce in a very precise way the phenomena present in the system but they require a high computational cost. The percentage difference between numerical and experimental results can be found in [11].

The design parameters of the EAHE are important in the ventilation capacity of the EAHE. Several studies [12-24] have shown that performance of an EAHE depends on several parameters: (i) the temperature decrease occurs during the first meters of EAHE, (ii) the difference in air temperature between the EAHE output and input decreases as the fluid velocity increases, (iii) the greater or the lower the temperature difference of the air at the entrance and the floor, the greater the heat transfer. On the other hand, those parameters that do not have a significant effect on performance are: (i) increasing the fluid velocity decreases the interaction time between soil and air, (ii) the greater the diameter, the greater the flow of air but greater pressure drops, (iii) the ventilation potential is very similar regardless of the material of the tube, (iv) increase the length of the tube after its optimal distance has small influence on the temperature difference. There is no optimal parameter in the EAHE that ensures perfect operation in all regions of the world, however from the results of the studies it can be concluded that the average values can be: (i) length of $50 \mathrm{~m}$, (ii) diameter of pipe between 100 and $200 \mathrm{~mm}$, (iii) fluid velocity between $1 \mathrm{~m} / \mathrm{s}$.

The operation of the EAHE depends on the soil conditions and properties because they influence the amount of heat that will be removed or supplied to the air. Several studies [25-33] have focused on studying aspects such as the temperature of the soil with respect to time or its content of humidity. These studies have shown that the higher the moisture content in the soil, the smaller the length necessary for the transfer of heat between the soil and the air. Additionally, the temperature of the soil varies from its initial value after a period of 6 hours, so that this can become detrimental in the performance of the EAHE, in these cases it is suggested that a period of rest be provided (EAHE out of operation).

Finally, aspects such as the geometry or coupling of EAHE with other types of systems that improve their performance have been studied by [34-42] developed an experimental and theoretical analysis of the thermal performance of EAHE integrated into a raft foundation in a building in Yilan, Taiwan. They showed that, the EAHE with the raft foundation presents a height of $1.3 \mathrm{~m}$, a thermal performance similar to an EAHE buried at $2 \mathrm{~m}$ depth from the ground, maintaining a constant exit temperature of $19,26,27$ and $28^{\circ} \mathrm{C}$ when the air enters a temperature of $20,31,30$ and $35^{\circ} \mathrm{C}$ on the simulated days.
Reference [37] evaluated the effect of the four geometric configurations on the thermal performance of an EAHE. The results showed that, an S-shaped configuration allows a good thermal performance of the EAHE in a smaller area of implementation $(37 \%)$ in comparison with the typical (horizontal) configuration and the other configurations. Reference [34] studied the effect of galvanized bridges on heat transfer by conduction of an EAHE, for different types of soil and environmental conditions. They showed that galvanized bridges improve heat dissipation by $90 \%$ in soils with low thermal conductivity while only improving by $13 \%$ for soils with high thermal conductivity.

From the previous review it can be observed that computational modeling of an EAHE has been evolving throughout the years; nevertheless, some parameters are still not considered since they turn the problem even more complex. Among these considerations we can find the heat accumulation under the ground, the heat contribution of the surface on the vertical pipes of the EAHE, the calculation of the convective heat transfer coefficient in the pipe, as well as the evaluation of the EAHE for any particular type of soil and any extreme climate conditions of a country.

The aim of this study is to carry out a pseudo-transient analysis of the conjugated heat transfer in a geothermal EAHE and to determine its potential of use in Mexico. For this study, six cities were selected, one for each of the most representative microclimate in the country: Villahermosa (hot-humid), Merida (hot-sub humid), Monterrey (dry), Juarez City (very dry), Zacualtipan-Hidalgo (warmhumid) and Mexico City (warm-sub humid). A $24 \mathrm{~h}$ evaluation was performed for the warmest and coldest day of the year for each city, with a 10 minutes time step and for three values of the Reynolds number.

\section{Physical model}

Figure 1a shows the physical model of a conventional EAHE with horizontal configuration because it is considered that this system is implemented in a house of social interest. The design of the EAHE consist of $5 \mathrm{~m}$ length, 0.15 diameter pipe buried $2 \mathrm{~m}$ depth. These characteristics are because the total area of social interest house is between 30 and $50 \mathrm{~m}^{2}$ (CONAVI, 2010), so there is not a large area for implementation of an EAHE. A layer of insulation $0.05 \mathrm{~m}$ thick is considered at the outlet of the EAHE so the air does not gain or lose energy at the exit of the pipe. Figure $1 \mathrm{~b}$ shows all the heat transfer processes occurring at the surface of the ground and Figure 1c the ones occurring inside the pipe.

The considerations for this study are:

For the soil

- Heat transfer analysis is in 2D.

- Beyond $2 \mathrm{~m}$ depth the soil temperature remains constant considering the work developed by $[43,44]$.

- Water evaporation is considered at the ground surface only.

- The thermophysical properties are constant and independent of the temperature. The values of thermal conductivity and specific heat are shown in Table 1. 


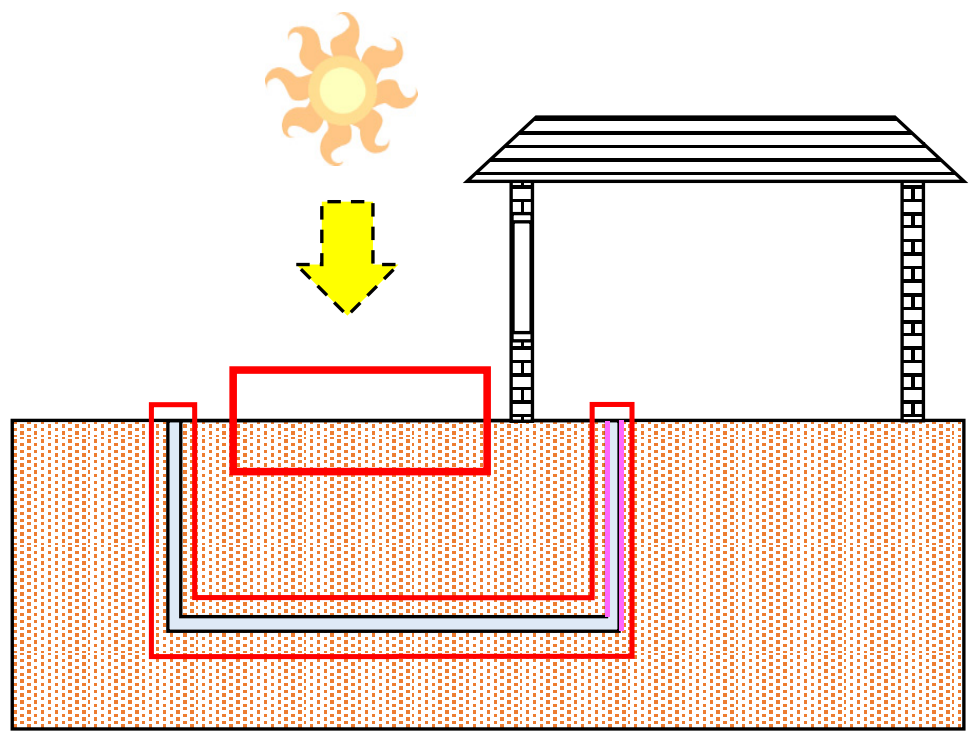

a)

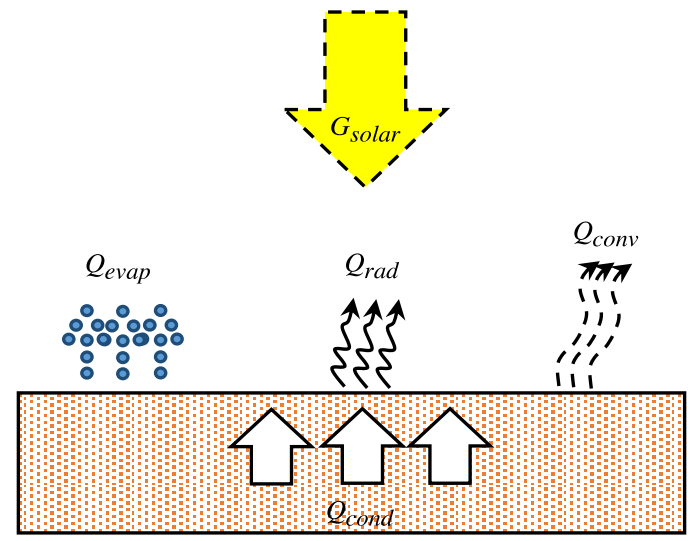

b)

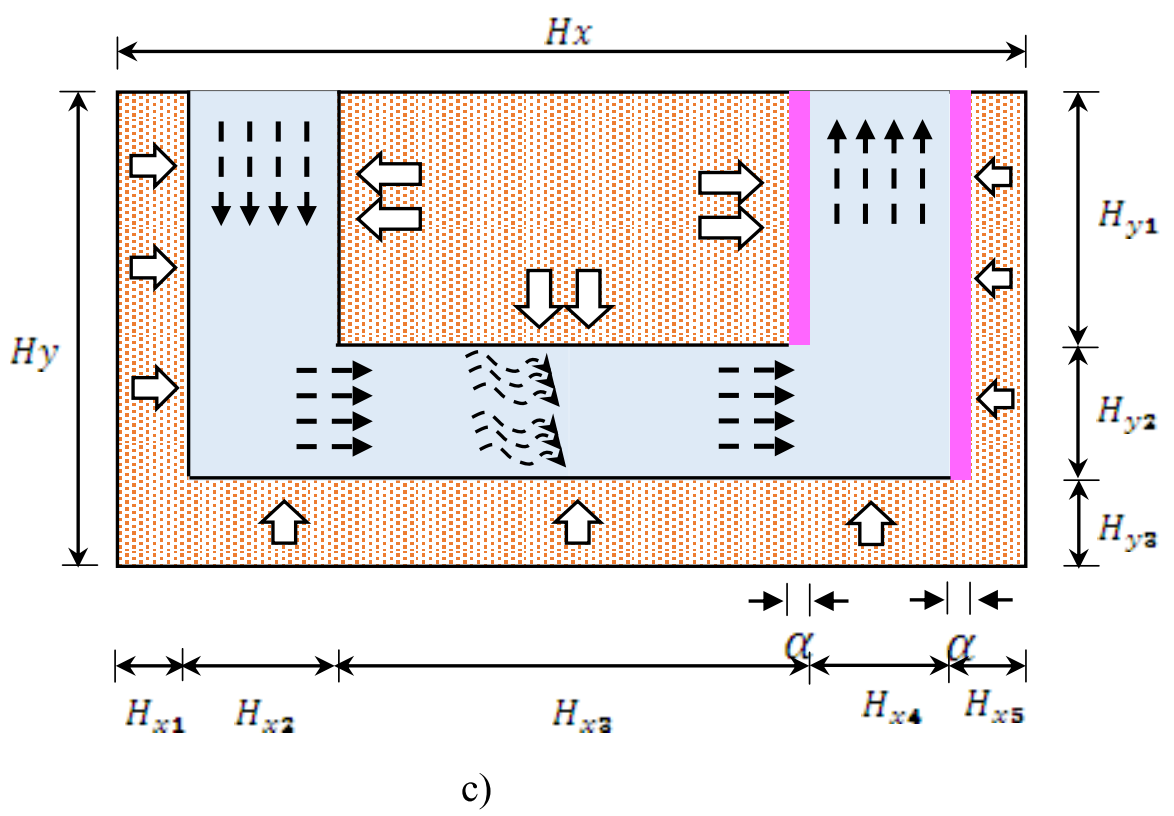

Fig. 1. Physical model of a geothermal EAHE: a) general view, b) heat transfer processes on the ground surface, c) heat transfer processes inside and around the pipes.

Table 1. Thermal properties.

\begin{tabular}{lll}
\hline Material & Conductivity $(\mathrm{W} / \mathrm{m} \mathrm{K})$ & Specific heat $(\mathrm{J} / \mathrm{g} \mathrm{K})$ \\
\hline Clay & 0.19 & 1114.6 \\
Lime & 0.19 & 1165.1 \\
Sand & 0.3 & 1502.5 \\
\hline
\end{tabular}

- The soil temperature is calculated numerically depending on the boundary conditions on the surface and how the air temperature inside the pipe is iteratively solved.
For the pipe

- Cross section is square since it does not affect the results accuracy [45].

- Heat conduction across the pipe wall is not taken into account because it is thin enough to be considered negligible.

- Neither condensation nor evaporation inside the pipe are taken into account.

- Convection is the prevailing heat transfer mechanism.

- Flow occurs in laminar regime because it is supposed that the aiflow is supplied for a low velocity fan. 
Table 2. Dimensions of each section of the geothermal EAHE.

\begin{tabular}{lll}
\hline Section & Symbol & Dimension \\
\hline Diameter of the vertical section of pipe & $H_{y 1}$ & $0.15 \mathrm{~m}$ \\
Depth of the pipe from the surface of the ground & $H_{y 2}$ & $2 \mathrm{~m}$ \\
Thickness of the soil layer under the horizontal pipe & $H_{y 3}$ & $1 \mathrm{~m}$ \\
Total depth & $\boldsymbol{H}_{\boldsymbol{y}}$ & $\mathbf{3 . 1 5} \mathbf{~ m}$ \\
Diameter of the horizontal sections of pipe & $H_{x 2}, H_{x 4}$ & $0.15,0.15 \mathrm{~m}=0.30 \mathrm{~m}$ \\
Thickness of the soil layer around the vertical pipes & $H_{x 1}, H_{x 5}$ & $0.5,0.5 \mathrm{~m}=1.0 \mathrm{~m}$ \\
Length of the pipe & $H_{x 3}$ & $5 \mathrm{~m}$ \\
Thickness of the insulating material & $\alpha$ & $0.05 \mathrm{~m}$ \\
Total length & $H_{x}$ & $6.30 \mathrm{~m}$ \\
\hline
\end{tabular}

Table 2 shows the dimensions for every section of the EAHE.

\section{Mathematical model}

Heat transfer across the soil occurs only by conduction, meanwhile inside the pipes heat transfer is by convection in laminar regime. The governing equations for the model of the EAHE are the continuity, momentum in $x$ and $y$ directions and energy equations, which can be solved depending on the time (transient state) or independent of this (steady state). Because a transient study requires more time and computational resources, in this study the concept of quasi-transient state was implemented, which consists in modeling several steady states in 10-minute intervals. Therefore, the governing equations can be expressed as:

$$
\begin{gathered}
\frac{\partial(\rho u)}{\partial x}+\frac{\partial(\rho v)}{\partial y}=0 \\
\frac{\partial(\rho u \cdot u)}{\partial x}+\frac{\partial(\rho u \cdot v)}{\partial y}=\frac{\partial}{\partial x}\left(\mu \frac{\partial u}{\partial x}\right)+\frac{\partial}{\partial y}\left(\mu \frac{\partial u}{\partial y}\right)-\frac{\partial P}{\partial x} \\
\frac{\partial(\rho v \cdot u)}{\partial x}+\frac{\partial(\rho v \cdot v)}{\partial y}=\frac{\partial}{\partial x}\left(\mu \frac{\partial v}{\partial x}\right)+\frac{\partial}{\partial y}\left(\mu \frac{\partial v}{\partial y}\right)-\frac{\partial P}{\partial y} \\
\frac{\partial(\rho u T)}{\partial x}+\frac{\partial(\rho v T)}{\partial y}=\frac{\partial}{\partial x}\left(\lambda \frac{\partial T}{\partial x}\right)+\frac{\partial}{\partial y}\left(\lambda \frac{\partial T}{\partial y}\right)
\end{gathered}
$$

The governing equations are subject to the following boundary conditions:

(a) East and west boundaries $\left(x=0\right.$ and $\left.x=H_{x}\right)$.

$$
\begin{aligned}
& \frac{\partial T}{\partial y}=0 \quad \text { in } \quad x=0 \quad \text { for } \quad 0 \leq y \leq H_{y} \\
& \frac{\partial T}{\partial y}=0 \quad \text { in } \quad x=H_{x} \quad \text { for } \quad 0 \leq y \leq H_{y}
\end{aligned}
$$

(b) South boundary $(y=0)$.

$$
\frac{\partial T}{\partial x}=0 \quad \text { in } \quad y=0 \quad \text { for } \quad 0 \leq x \leq H_{x}
$$

(c) North boundary $\left(y=H_{y}\right)$.

The energy balance model proposed by [46] was used to model the conduction, convection and radiation heat transfer at the north boundary on the soil surface and it is given by:

$$
\begin{gathered}
-Q_{\text {cond }}=-Q_{\text {conv }}(C E)+Q_{\text {rad }}(L R)-\alpha G(S R) \\
+Q_{\text {evap }}(L E) \text { in } y=H_{y} \quad \text { for } \\
0 \leq x \leq H_{x}
\end{gathered}
$$

where

i.) $C E$ is the convective energy exchange between the air and the surface of the ground given by [46]:

$$
Q_{\text {conv }}=h_{\text {sur }}\left(T_{\text {amb }}-T_{\text {sur }}\right)
$$

where $T_{a m b}$ is the ambient temperature of the corresponding day of modeling, $T_{\text {sur }}$ is the temperature on the surface of the ground, $h_{\text {sur }}$ is the convective heat transfer coefficient at the surface of the soil, computed as [47]:

$$
\begin{aligned}
& h_{\text {sur }}= 5.678\left[0.775+0.35\left(\frac{v e l_{\text {wind }}}{0.304}\right)\right] \\
& \text { for } \quad v e l_{\text {wind }}<4.88 \\
& h_{\text {sur }}= 5.678\left[0.775+0.35\left(\frac{v^{2 e l_{\text {wind }}}}{0.304}\right)^{0.78}\right] \\
& \text { for } \quad \text { vel }_{\text {wind }} \geq 4.88
\end{aligned}
$$

ii.) SR is the long wave solar radiation absorbed by the surface of the soil, computed as [46]:

$$
S R=\alpha G
$$

where $\alpha$ is the absorptivity of the soil and $G$ is the incident solar radiation on its surface $\left(\mathrm{W} / \mathrm{m}^{2}\right)$. 
iii.) LR is the long wave radiation calculated by:

$$
L R=\varepsilon \Delta R
$$

where $\varepsilon$ is the emmitance of the soil surface and $\Delta R$ is a term that depends on the relative humidity of the soil and the air on its surface. Some studies have proved that $63 \mathrm{~W} / \mathrm{m}^{2}$ seems to be an appropriate value for this variable [47].

iv.) LE is the latent heat from the surface of the soil due to evaporation an can be computed by [46]:

$$
L E=0.0168 f h_{\text {sur }}\left[\left(a T_{\text {sur }}+b\right)-H R\left(a T_{a m b}+b\right)\right]
$$

where $R H$ is the relative humidity of the environmental air, $a$ and $b$ are $103 \mathrm{PaK}^{-1}$ y $609 \mathrm{~Pa}$ respectively [46] and $f$ is a fraction which depends mainly on the ground cover and on the humidity level of the ground. The fraction $f$ can be estimated as follows [46]:

$$
\begin{array}{ll}
f=1 & \text { Saturated soil (bare soil) } \\
f=0.6-0.8 & \text { Moist soil (bare soil) } \\
f=0.7 & \text { For grass covered soil. } \\
f=0.4-0.5 & \text { Dry soil (bare soil) } \\
f=0.1-0.2 & \text { Arid soil (bare soil) } \\
\text { a) Inlet air supply } & (y=H y)
\end{array}
$$

The air inlet temperature is considered to be at the same temperature that environmental air at a constant velocity, defined by the Reynolds number as:

$v=f(R e), u=0 \quad$ in $\quad y=H_{y} \quad$ for $\quad H_{x 1} \leq x \leq H_{x 3}$

b) Outlet air flow $(y=H y)$.

$$
\begin{array}{cc}
\frac{\partial T}{\partial y}=0, \frac{\partial u}{\partial y}=0 & \text { and } \quad \frac{\partial v}{\partial y}=0 \quad \text { in } \\
y=H_{y} \quad \text { for } \quad H_{x 3} \leq x \leq H_{x 5}
\end{array}
$$

To achieve the numerical solution of the EAHE, the system is considered as if it all were a fluid where the physical properties are assigned according to the location of the computational node in the system, and its values are recalculated at the control-volume faces by interpolations. Subsequently, a blocking off technique is used for the sections corresponding to the soil, where the velocity assigned to these computational elements is zero; this way, the hydrodynamic effect in the soil is nullified taking place heat transfer by conduction only.

\section{Numerical methodology}

The numerical methodology starts by discretizing the governing equations using the finite volume method and implementing a central scheme to deal with the conductive terms and the hybrid scheme with the convective terms. Coupling between the momentum and continuity equations was carried out by the SIMPLE algorithm $[48,49]$. In order to assure good accuracy in the results, the convergence criterion was set as $10^{-10}$ for all the variables.

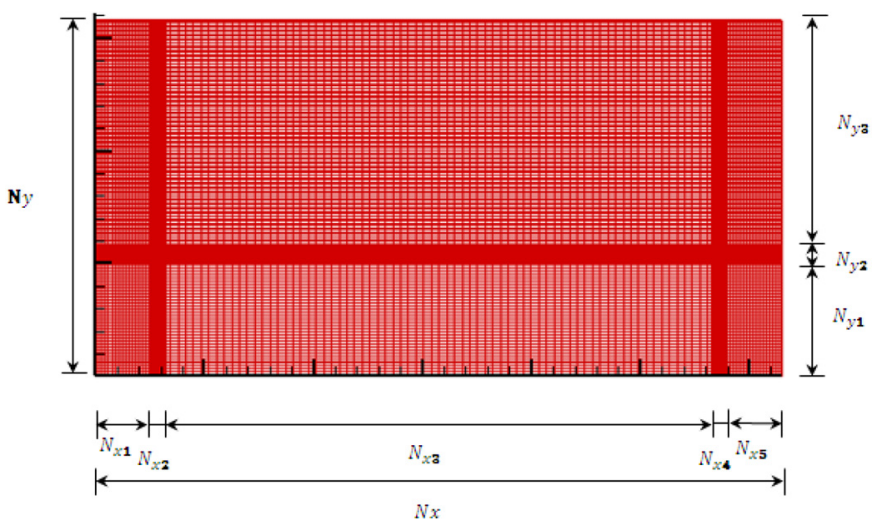

Fig. 2. Domain computational.

Figure 2 shows the discretization of the physical domain of the EAHE into a computational mesh, where the areas corresponding to the pipes have a finer mesh than the areas representing the soil. A study of independence of mesh was carried out in order to find the adequate number of nodes to represent the diameter and length of the pipe, this study was implemented with the largest value of the Reynolds number $(R e=1500)$ and the highest temperature in Juarez City since it has extreme weather conditions. The weather data used in the analysis were: temperature $46.6{ }^{\circ} \mathrm{C}$, solar radiation $786 \mathrm{~W} / \mathrm{m}^{2}$, relative humidity $5 \%$ and wind speed $1.5 \mathrm{~m} / \mathrm{s}$.

The study of independence of mesh was developed in two steps; the first step consisted on varying the number of nodes in $N_{x 3}$ from 71 to 111 in increments of ten, while the other directions remained constant. After 101 nodes in this section no significant changes were observed regarding the velocity and temperature variables, with 0.01 and $0.02 \%$ respectively. Later, the number of nodes in $N_{x 2}, N_{x 4}$ and $N_{y 2}$ were varied from 51 to 91 , and no significant changes were observed after 71 nodes with differences lower than $0.14 \%$ and $0.1 \%$ for the velocity and temperature respectively. Table 3 shows the number of nodes assigned to each section of the EAHE, making a total of 285 in $x$ direction and 213 in $y$ direction $(285 \times 213)$.

The final methodology of solution can be described as follows:

- Initial values are input $\left(N_{x}, N_{y}\right.$, EAHE data, weather data, etc)

- Generation of mesh

- Thermal and physical properties are assigned according to the location of the computational node.

- Definition of the guessed velocity and temperature fields.

- Apply the SIMPLE algorithm to solve the velocity field using the turn-off technique.

- Solve the energy equation to find the temperature field.

- Apply the convergence criterion.

- Repeat the procedure until the convergence criterion is satisfied.

The in-house code was subjected to a verification process by solving the "differentially heated cavity with an embedded solid" problem reported by [50]. The problem consisted on determining the velocity and temperature fields of the air inside a cavity with a solid at the center, in steady state and natural convection. The cavity is 
Table 3. Number of nodes for each section of the geothermal EAHE.

\begin{tabular}{lll}
\hline Section & Symbol & Nodes \\
\hline Pipe diameter & $N_{y 2}, N_{x 2}, N_{x 4}$ & 71 \\
Distance from the ground surface to the pipe & $N_{y 3}$ & 101 \\
Length of the soil layer after the pipe & $N_{y 1}$ & 41 \\
Length of the soil layer around the vertical pipes & $N_{x 1}, N_{x 5}$ & 21 \\
Length of the pipe & $N_{x 3}$ & 101 \\
\hline
\end{tabular}

differentially heated on the vertical walls $\left(T_{H}=25^{\circ} \mathrm{C}\right.$ and $\left.T_{C}=15^{\circ} \mathrm{C}\right)$. The thermal conductivity of the solid is determined as a function of the thermal conductivity ratio and the length $H$ of the cavity, which are calculated based on the Rayleigh number. Results were obtained for a Rayleigh number of $10^{5}$ and conductivity ratios of 0.2 and 5.0 , and the Nusselt number was compared to the reference. The absolute percentage difference between the present work and the reference was 0.6 and $0.7 \%$ for the corresponding conductivity ratios respectively. Then, it can be concluded that the numerical code gives satisfactory results for the conjugate heat transfer problem.

\section{Results and discussion}

In this section the results from the modeling of the EAHE are presented, for Reynolds number of 100, 750 and 1500. The type of soil in each city was silt in Mexico City, sand in Juarez City, clay in Merida, clay in Villahermosa, limestone in Zacualtipan-Hidalgo and limestone in Monterrey [51,52] For the modeling, the warmest and coldest day of the year for each city was considered, and weather data every 10 minutes. These cities were chosen mainly for two reasons: (i) they are capital cities which involve a large population index and (ii) each one of them is representative of the main micro-climates in Mexico.

The weather data involved in the modeling were ambient temperature, relative humidity, wind velocity and solar radiation every 10 minutes, for the warmest and coldest day of the year in each city. However, for practicality the meteorological information presented in Tables 4-9 is shown in intervals of one hour; the data was provided by [53].

Results are presented for (i) air temperature, (ii) mass flow rate and (iii) air velocity, all data at the outlet of the EAHE.

\subsection{Air temperature at the outlet of the EAHE}

In this section, the air temperature at the outlet of the EAHE as well as the difference between the inlet and outlet air temperature are presented, for the warmest and coldest day of each city.

\subsubsection{Villahermosa}

Figure 3 shows the air temperature at the outlet of the EAHE for the three Reynolds number compared to the ambient temperature for the warmest and coldest day. In this figure (Fig. 3a) we can observe that during the first hours of the day, from 0:00 to 8:00 h, the thermal performance of the EAHE is acceptable, keeping the air outlet temperature below the ambient temperature, mainly for the lowest Reynolds number, with a decrement of up to $2.5^{\circ} \mathrm{C}$, as shown in Figure 3b. Nevertheless, after 8:00 h, as solar radiation starts increasing, the cooling effect diminishes, presenting even an increment of the air outlet temperature of up to $15^{\circ} \mathrm{C}$ compared to the ambient temperature, this adverse effect seems to be less intense at higher Reynolds number. After midday, this phenomenon is reversed and at 14:00 h the air outlet temperature stays down and keeps lower than the ambient temperature. The maximum decrement in temperature was $8.9^{\circ} \mathrm{C}$, achieved at 17:00 h for $R e=100$.

For the cold day, in Figure 3 can be observed that from 0:00 to 8:00 hrs, the EAHE performs moderately adequate for $R e=750$ and $R e=1500$, with an increment of the air outlet temperature of $1.5^{\circ} \mathrm{C}$; nevertheless, the case for $R e=100$ has the opposite effect, decreasing the outlet temperature for up to $2.5^{\circ} \mathrm{C}$. From 8:00 to $14: 00 \mathrm{~h}$ the heating capacity improves mainly for $R e=100$, showing an increment of the outlet temperature of $6.2{ }^{\circ} \mathrm{C}$ at $9: 50 \mathrm{~h}$. As solar radiation starts diminishing so does the heating capacity of the EAHE for the three Reynolds number, which after 14:00 h gradually delivers air with a temperature lower than the ambient, reaching a maximum decrement of $5.0^{\circ} \mathrm{C}$ at $17: 00 \mathrm{~h}$ for a $R e=100$.

For both, the warmest and coldest day the EAHE showed mainly a cooling effect, which for a city where ambient temperatures are high even in winter, can result the most benefit.

\subsubsection{Merida}

Figure 4 shows the thermal performance of the EAHE for the three Reynolds number and the warmest and cold day in Merida. As can be seen in this figure for the warmest day condition (Fig. 4a, b), from 0:00 to 8:00 h, the EAHE diminishes the air outlet temperature between 1.5 and $3{ }^{\circ} \mathrm{C}$, with the lowest temperature for the $R e=100$. After 8:00 h, as solar radiation increases so does the ambient temperature, but the EAHE still keeps the air outlet temperature lower, especially for $R e=1500$. Between 8:00 and 16:00 h the maximum air outlet temperature decrement is $8.4^{\circ} \mathrm{C}$ at 15:50 h, with the ambient temperature above $40^{\circ} \mathrm{C}$. As solar radiation and the ambient temperature go down the cooling capacity diminishes, although the air outlet 


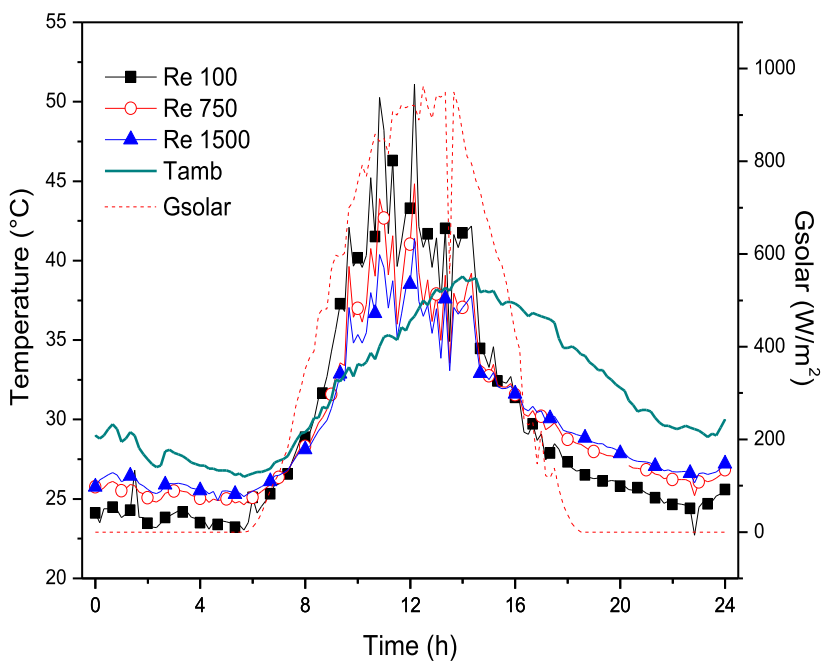

(a)

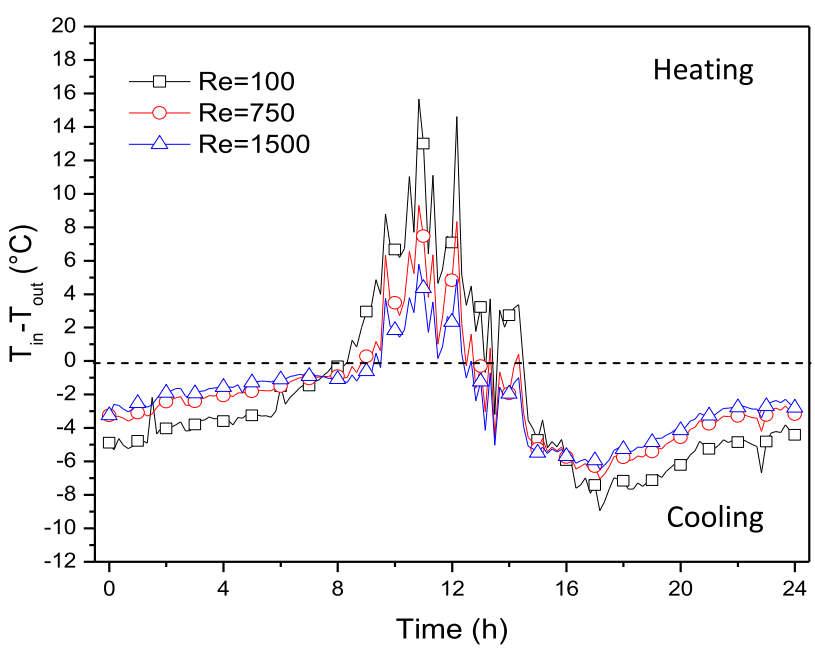

(b)

\section{Warmest day}

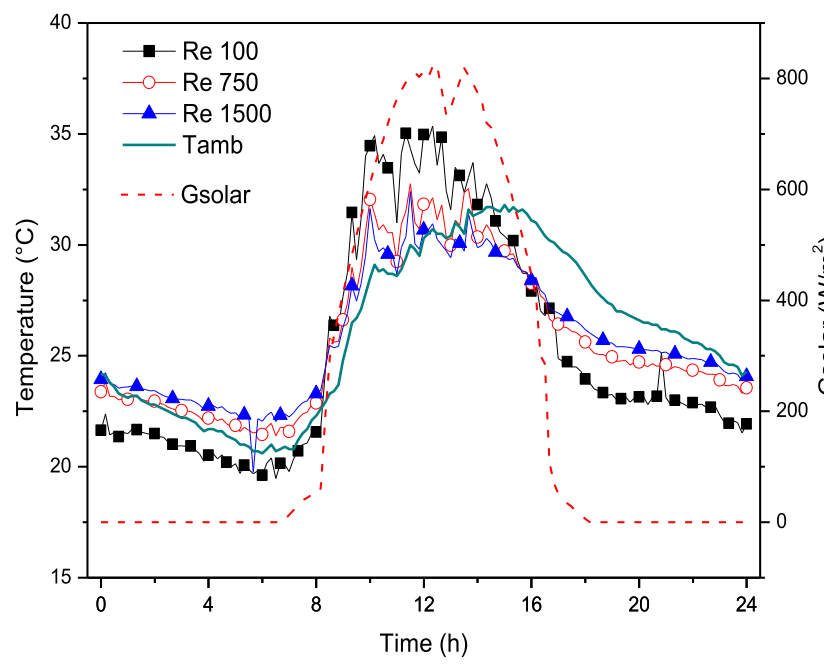

(c)

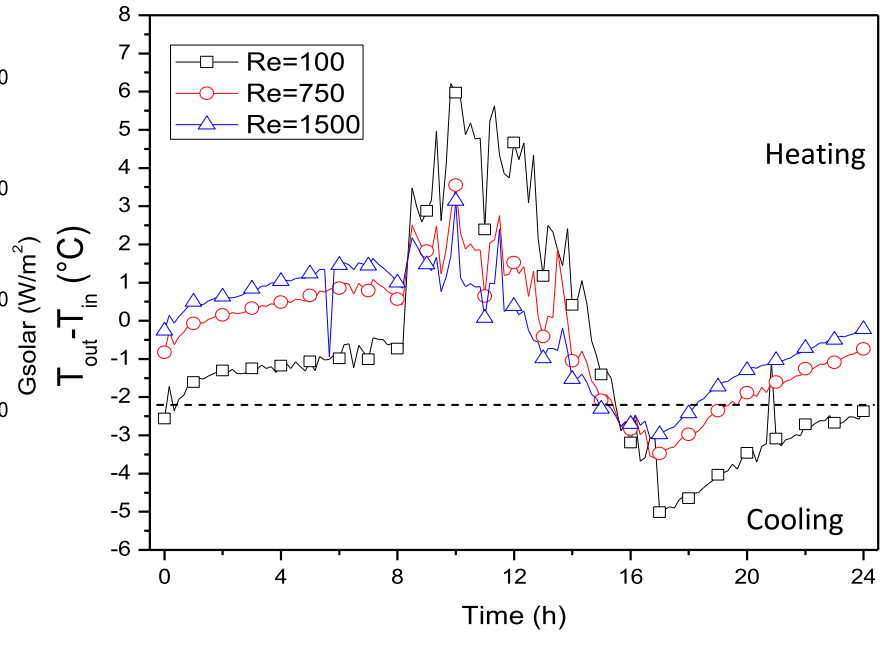

(d)

\section{Coldest day}

Fig. 3. Thermal behavior of the EAHE for the warmest and coldest day in Villahermosa.

temperature still remains lower than the ambient temperature, mainly for a $R e=100$. The maximum air outlet temperature decrement during the whole day was $13.3^{\circ} \mathrm{C}$ at $16: 20 \mathrm{~h}$ when the ambient temperature was at $38.8^{\circ} \mathrm{C}$.

The heating capacity of the EAHE for the coldest day of Merida and the three Reynolds is shown in Figure 4c,d. Between 0:00 and 8:00 h the EAHE shows a good heating capacity mainly for high Reynolds number, $R e=750$ and $R e=1500$, with a maximum increment in temperature of $3.2^{\circ} \mathrm{C}$ at $2: 50 \mathrm{~h}$ As the ambient temperature increases due to solar radiation, the heating capacity starts diminishing, getting both temperatures (inlet and outlet) very close to each other between 9:30 and 13:20 h. After this time, as solar radiation decreases between 13:30 and 18:00 h, the EAHE cools the air for all the three Reynolds number. But beyond 18:00 h, the EAHE resumes its heating function for $R e=750$ and $R e=1500$ although with a less significant impact than during the morning, being the largest increment of the outlet temperature of $1.1^{\circ} \mathrm{C}$ for the $R e=1500$.

\subsubsection{Monterrey}

Figure 5 shows the thermal behavior of the EAHE for the warmest and cold day in Monterrey and the three Reynolds number, for the warmest day the performance of the EAHE seems to be significantly good, since the air outlet 


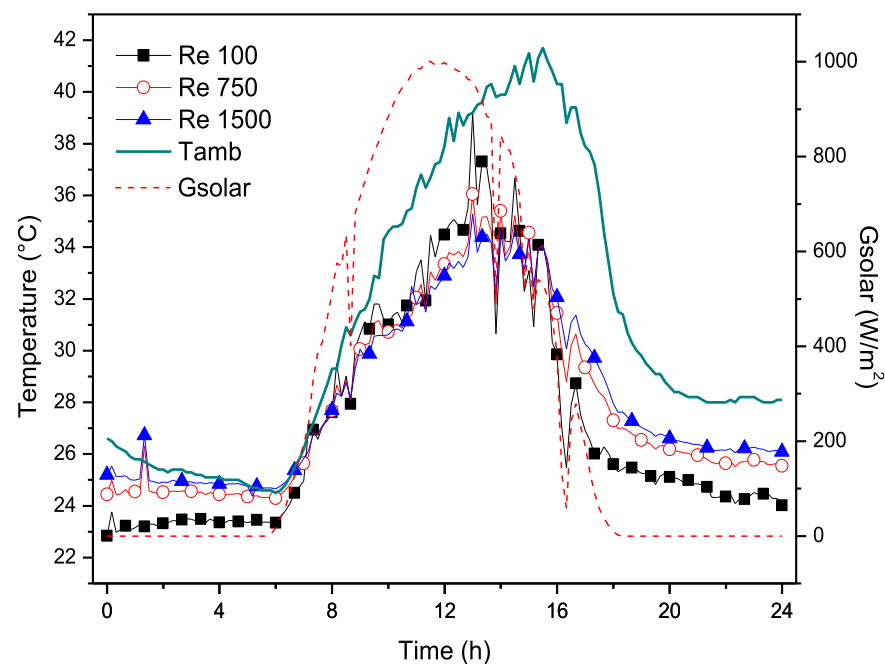

(a)

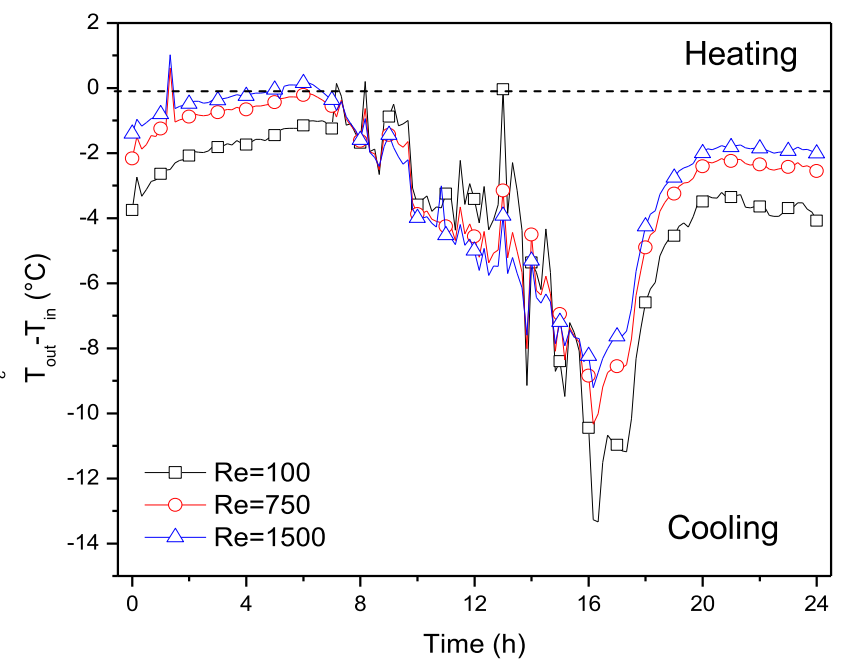

(b)

\section{Warmest day}

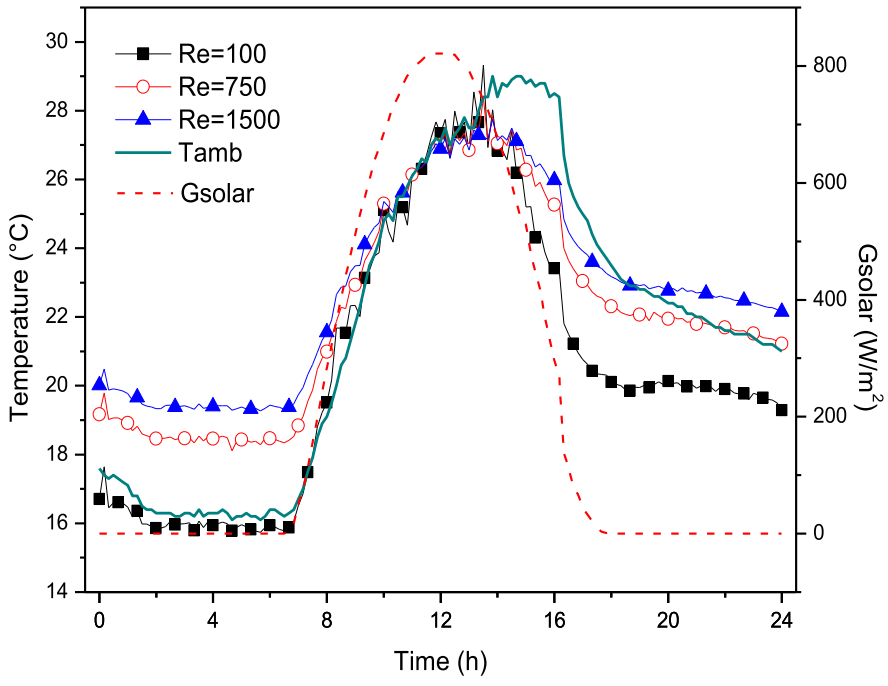

(c)

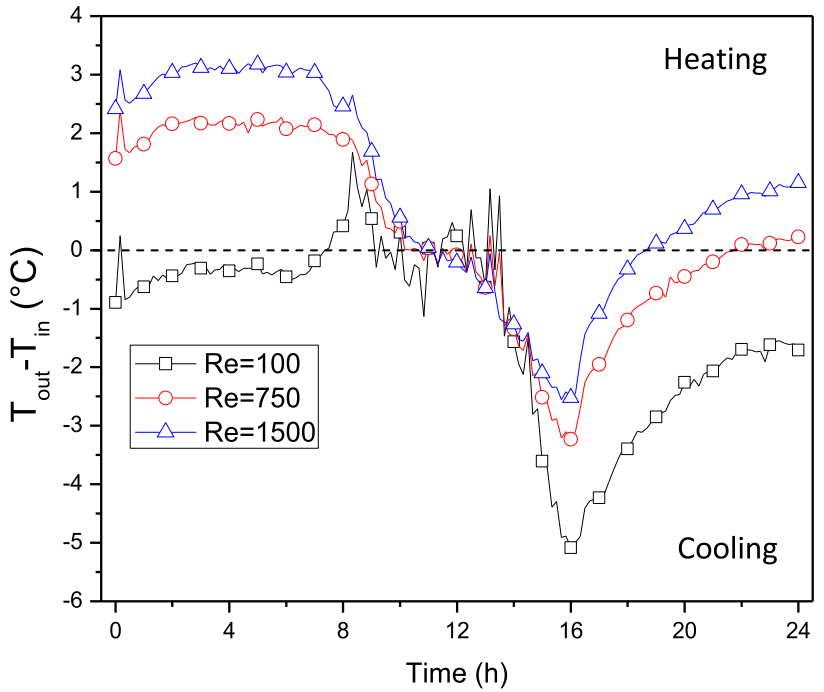

(d)

\section{Coldest day}

Fig. 4. Thermal behavior of the EAHE for the warmest and coldest day in Mérida.

temperature remains below the ambient temperature along the whole day for the three Reynolds number, especially for $R e=100$, with decrements in temperature for up to $12.9^{\circ} \mathrm{C}$ at $8: 00 \mathrm{~h}$ and $15.8^{\circ} \mathrm{C}$ at $15: 50 \mathrm{~h}$, with the maximum decrement of $17.6^{\circ} \mathrm{C}$ achieved at $18: 30 \mathrm{~h}$, while the ambient temperature was at $40,41.5$ and $36.4^{\circ} \mathrm{C}$, respectively.

Figure 5c,d shows the results for the coldest day in Monterrey, where the EAHE performs very efficiently almost along the whole day for $R e=750$ and $R e=1500$ increasing the air outlet temperature for up to $4.2{ }^{\circ} \mathrm{C}$ at 8:00 h, with an ambient temperature of $6^{\circ} \mathrm{C}$, and reaching a maximum of $9.7^{\circ} \mathrm{C}$ at $11: 00 \mathrm{~h}$. Although the heating capacity diminishes after midday, the air outlet temperature still remains above the ambient temperature almost the rest of the day. On the other hand, for $R e=100$, the heating capacity only works between 8:00 and 17:00 h, other time than that it behaves like a cooler.

\subsubsection{Juarez City}

The numerical results for the warmest and cold day in Juarez City are shown in Figure 6. From these figures it can be seen that the performance of the EAHE is remarkable, where the cooling effect of the EAHE remains all day long, showing the best performance for $R e=100$, with a decrement of the air outlet temperature of $13.7^{\circ} \mathrm{C}$ at 


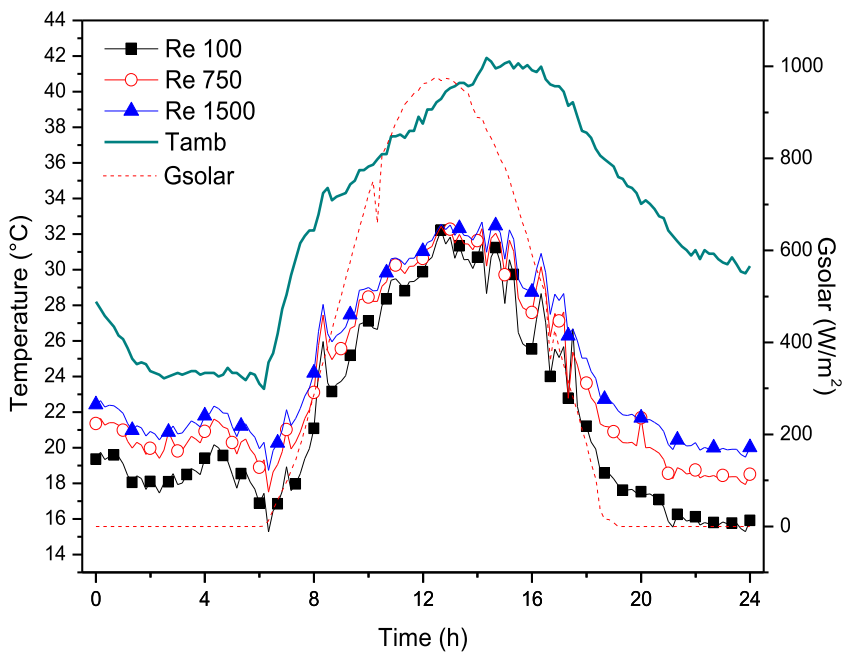

(a)

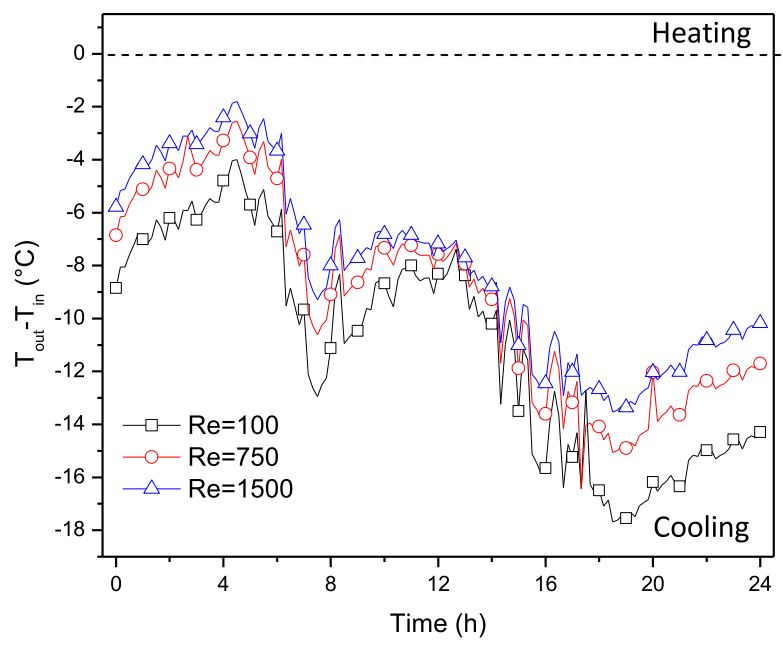

(b)

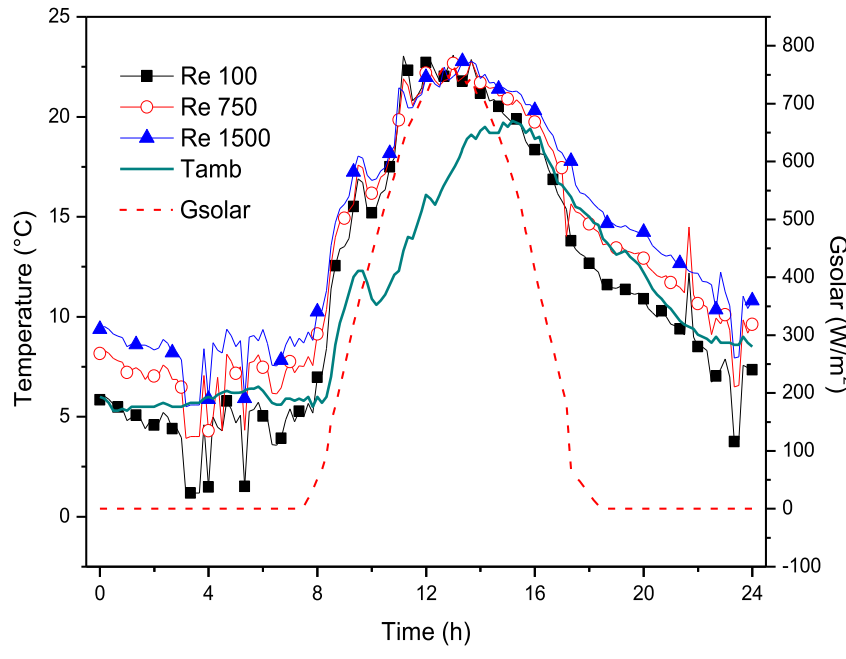

(c)

\section{Warmest day}

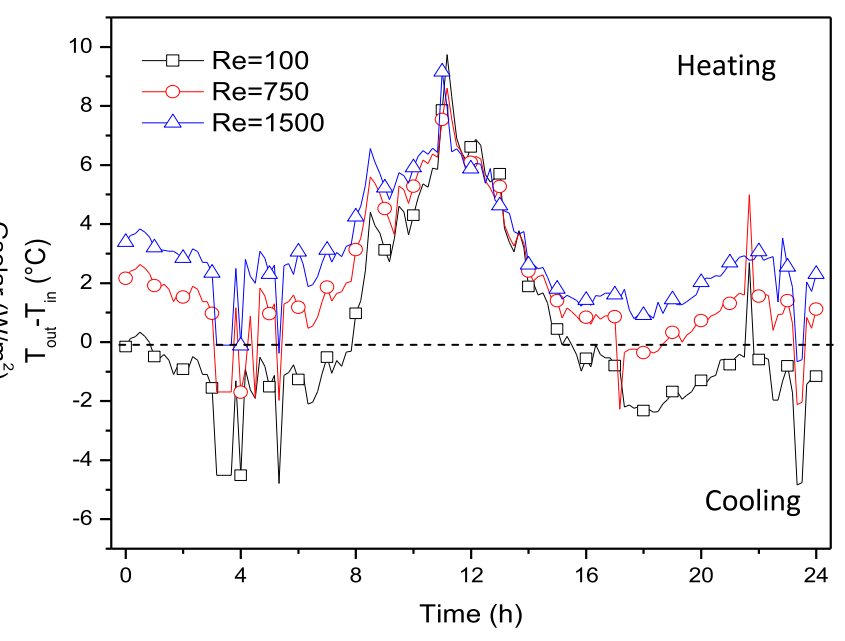

(d)

\section{Coldest day}

Fig. 5. Thermal behavior of the EAHE for the warmest and coldest day in Monterrey.

8:00 h, with the ambient temperature at $34.3^{\circ} \mathrm{C}$. Within the next few hours, the cooling effect presents a small reduction with a decrement in the air outlet temperature of $11.3^{\circ} \mathrm{C}$ with the ambient temperature above $40^{\circ} \mathrm{C}$. After noon the cooling performance improves significantly, reaching a temperature difference of $18.5^{\circ} \mathrm{C}$ at $20: 30 \mathrm{~h}$, when ambient temperature is at $38.3^{\circ} \mathrm{C}$.

Figure $6 \mathrm{c}, \mathrm{d}$ shows the thermal behavior of the EAHE for the coldest day in Juarez City as a function of the Reynolds number. From these figures it can be seen that all day long, the EAHE performs as a heater, especially for high Reynolds number $(R e=1500)$. Although between 0:00 and 8:00 h the ambient temperature is below freezing, the EAHE raises the air outlet temperature moderately, for up to $7.4^{\circ} \mathrm{C}$ at $7: 40 \mathrm{~h}$. As the solar radiation increases so does the air outlet temperature, reaching a maximum increment of $10.2^{\circ} \mathrm{C}$ for a $R e=1500$ at $16: 00 \mathrm{~h}$; after that time the heating capacity of the EAHE diminishes getting even colder temperatures than the ambient for low Reynolds number $(R e=100)$.

\subsubsection{Zacualtipan-Hidalgo}

The EAHE shows a good performance of the EAHE for the warmest day in Zacualtipan-Hidalgo, as observed in Figure $7 \mathrm{a}$ and $\mathrm{b}$. In the early morning between 0:00 and 8:00 h, the air outlet temperature reduces for up to $9.8^{\circ} \mathrm{C}$ compared to the ambient temperature for $R e=100$, meanwhile the cooling capacity for high Reynolds number is less significant. As the ambient temperature rises 


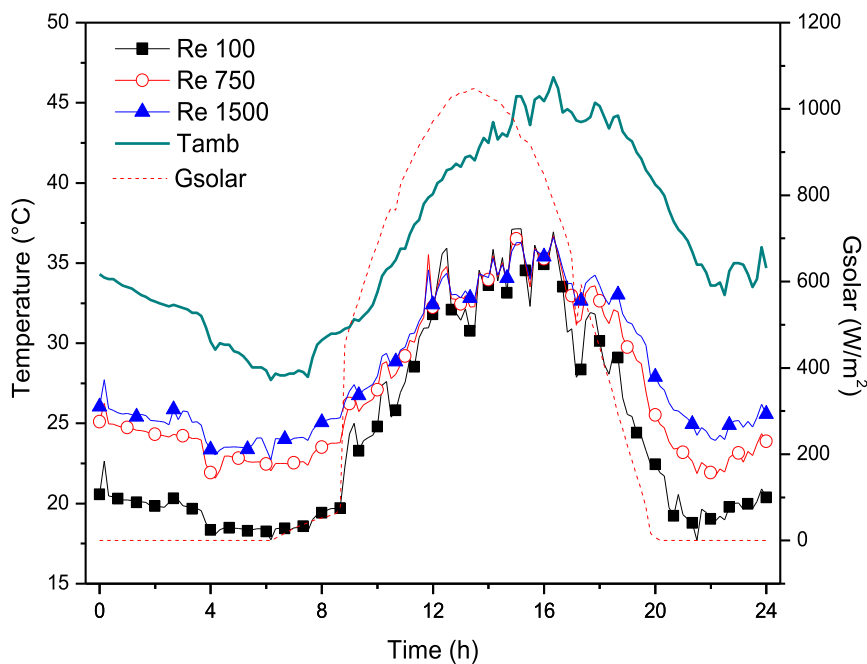

(a)

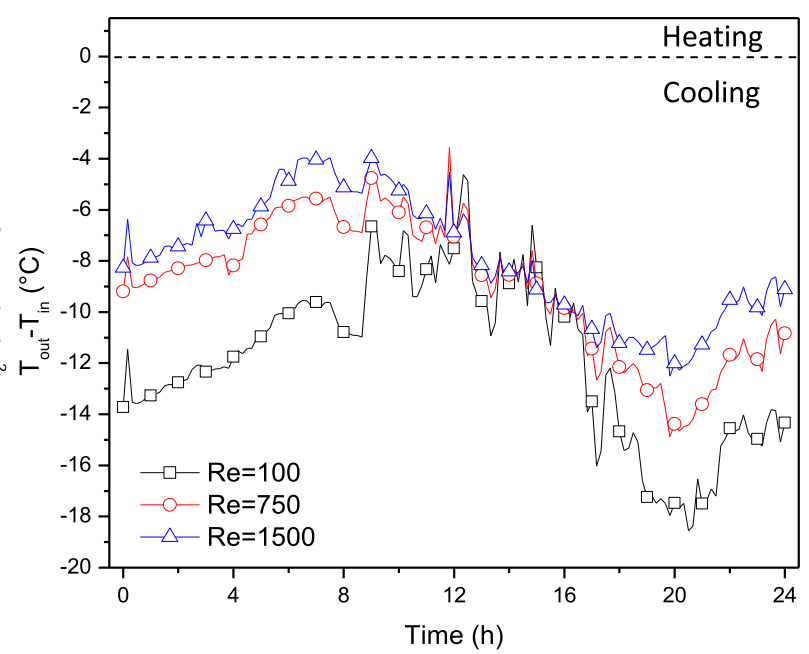

(b)

\section{Warmest day}

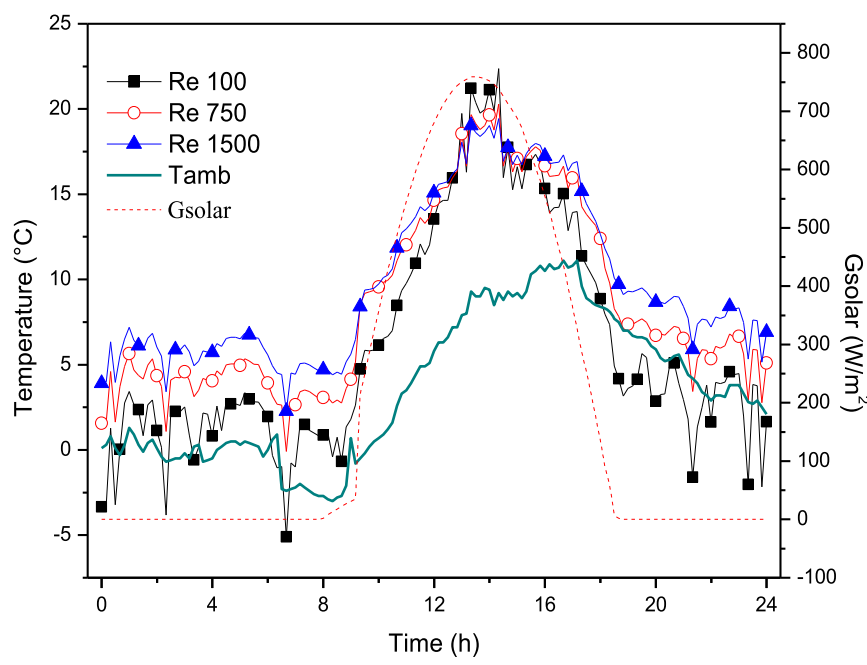

(c)

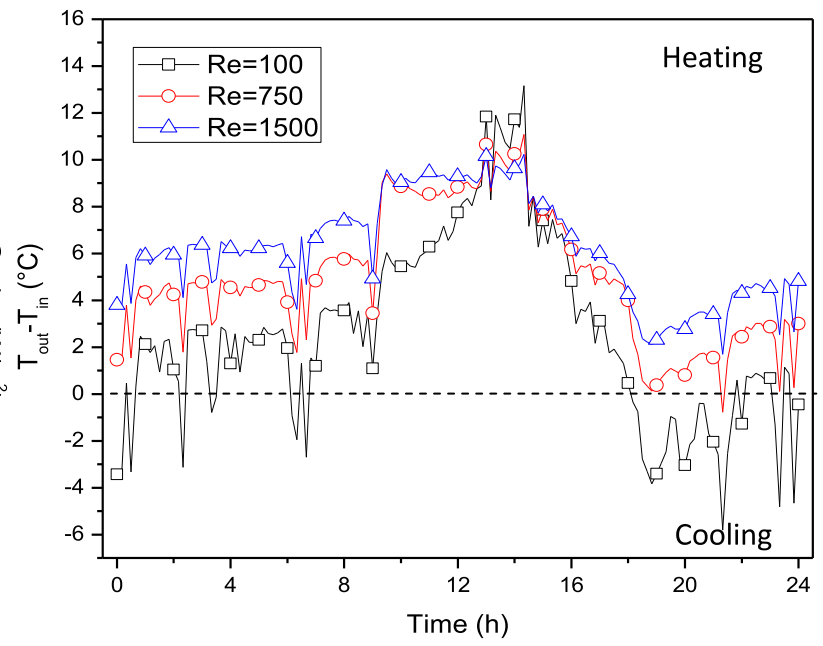

(d)

\section{Coldest day}

Fig. 6. Thermal behavior of the EAHE for the warmest and coldest day in Juarez City.

between 8:00 and 14:00 h, the cooling capacity for $R e=100$ reduces quickly getting closer to the other two. After 14:00 h the cooling capacity for all three Reynolds number rises again, reaching at 16:00 $\mathrm{h}$ a temperature difference of $12{ }^{\circ} \mathrm{C}$ when the ambient temperature is at $32.4^{\circ} \mathrm{C}$; later, the cooling capacity of all three $R e$, reduces significantly such that, at the end of the day the outlet temperature almost equals the ambient temperature.

The numerical results of the thermal performance for the coldest day of Zacualtipan-Hidalgo and the three Reynolds number are shown in Figure $7 \mathrm{c}$ and d, where we observe that from 0:00 to 8:00 h the outlet temperature rises moderately for high Reynolds number ( $R e=750$, $R e=1500$ ) and they stay stable during this period of time, with a maximum increment of $3.5^{\circ} \mathrm{C}$; meanwhile, for low Reynolds number $(R e=100)$ occurs the opposite, that is to say, the outlet temperature gets even lower than the ambient temperature. Between 8:00 and 16:00 h, as the ambient temperature rises so do the heating capacity for all three Reynolds number, approaching each other and keeping this way, reaching a maximum increment in temperature of $8.2^{\circ} \mathrm{C}$ for $R e=1500$ at 8:00 h. After $16: 00 \mathrm{~h}$, the heating capacity of the EAHE for the three Reynolds number reduces significantly as they start moving away 


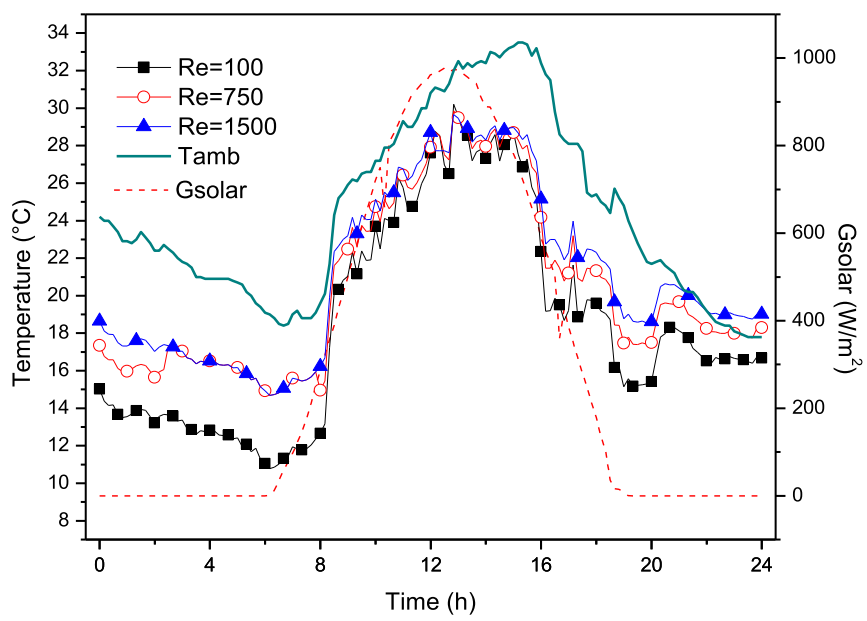

(a)

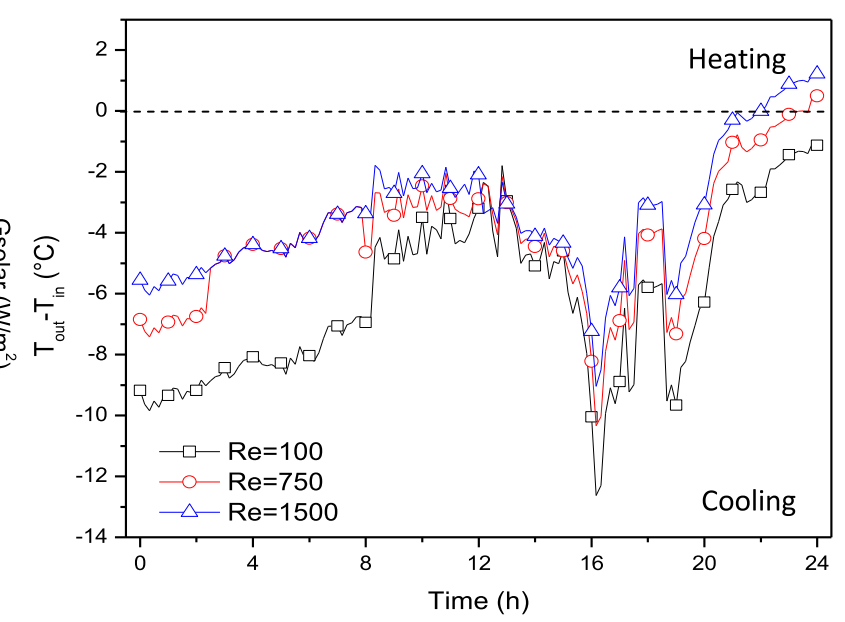

(b)

\section{Warmest day}

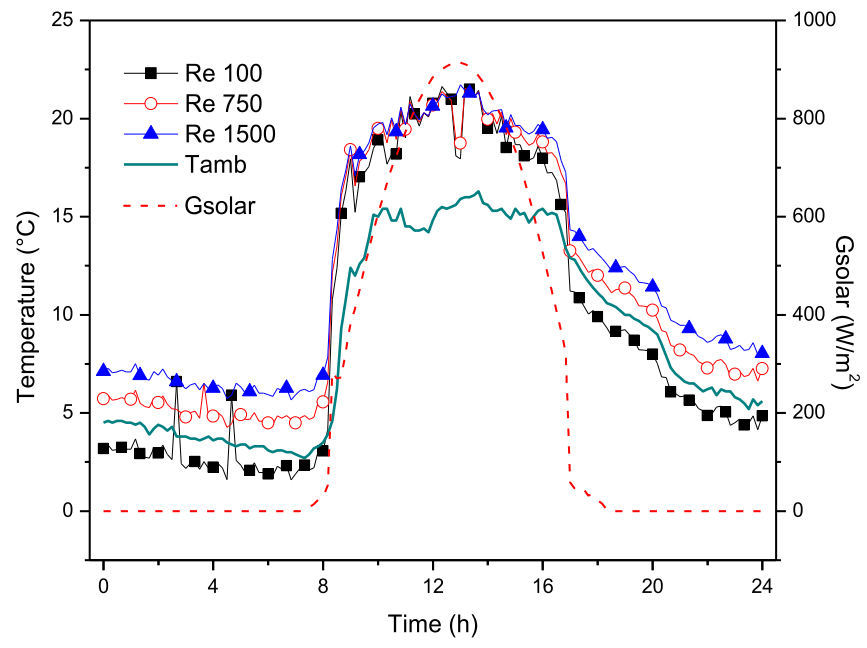

(c)

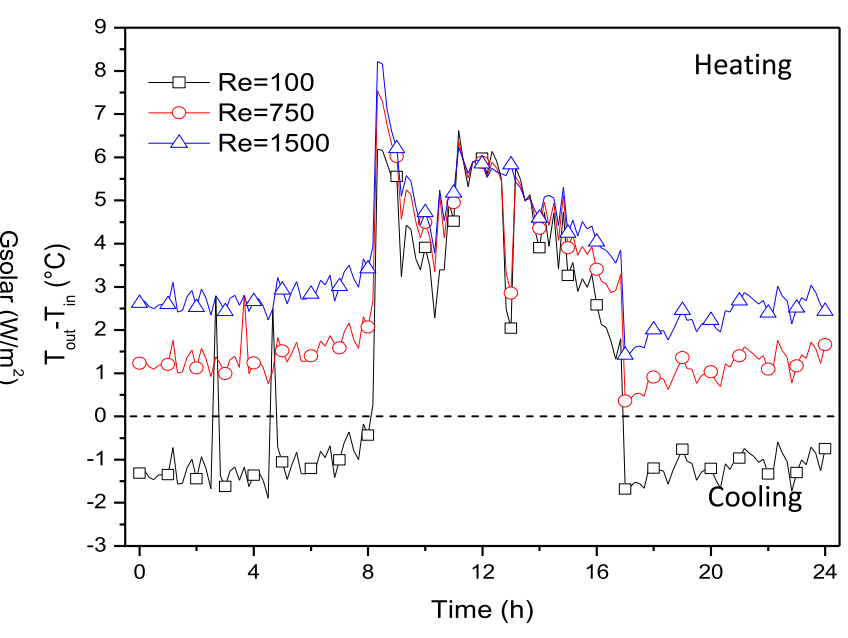

(d)

\section{Coldest day}

Fig. 7. Thermal behavior of the EAHE for the warmest and coldest day in Zacualtipan-Hidalgo.

from each other until they reach the initial state they had at the beginning of the day. At this period of time, the maximum increment in temperature was 3.9 and $1.4^{\circ} \mathrm{C}$ for $R e=750$ and $R e=1500$, as for $R e=100$ the air outlet temperature decreases rather than increasing.

\subsubsection{Mexico City}

The results for the performance of the EAHE in the warmest day are shown in Figure 8a,b. Figure 8b shows that from 0:00 to 8:00 h the system works adequately for low Reynolds number $(R e=100)$, with a decrement of the air outlet temperature of up to $6.3^{\circ} \mathrm{C}$, while for high Reynolds number $(R e=750, R e=1500)$ the air outlet temperature is very close to the ambient temperature. As solar radiation increases, so does the ambient temperature, and the air outlet temperature rises beyond the ambient temperature, reaching a maximum increment of $12^{\circ} \mathrm{C}$ at noon. Later, the outlet temperature gradually decreases, and after 14:00 $\mathrm{h}$ the cooling effect emerges again reaching a decrement of the air outlet temperature of up to $10.2^{\circ} \mathrm{C}$ showing a better performance for low Reynolds number $(R e=100)$.

Figure $8 \mathrm{c}$ and $\mathrm{d}$ shows the numerical results for the coldest day, where it can be seen that the system increases the air outlet temperature during the whole day. Between 0:00 and 8:00 h the temperature increases moderately, with a maximum of $7^{\circ} \mathrm{C}$ for a high Reynolds number 


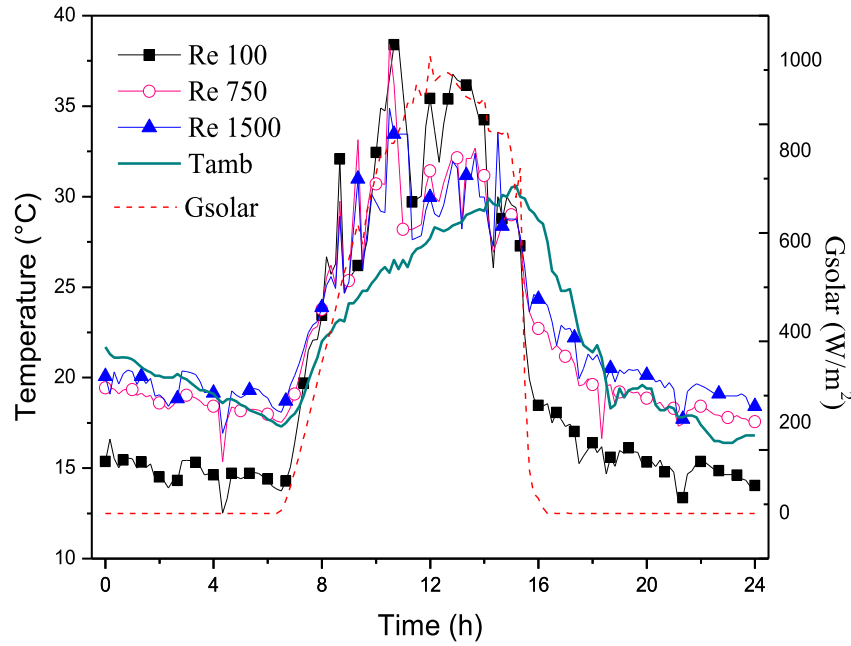

(a)

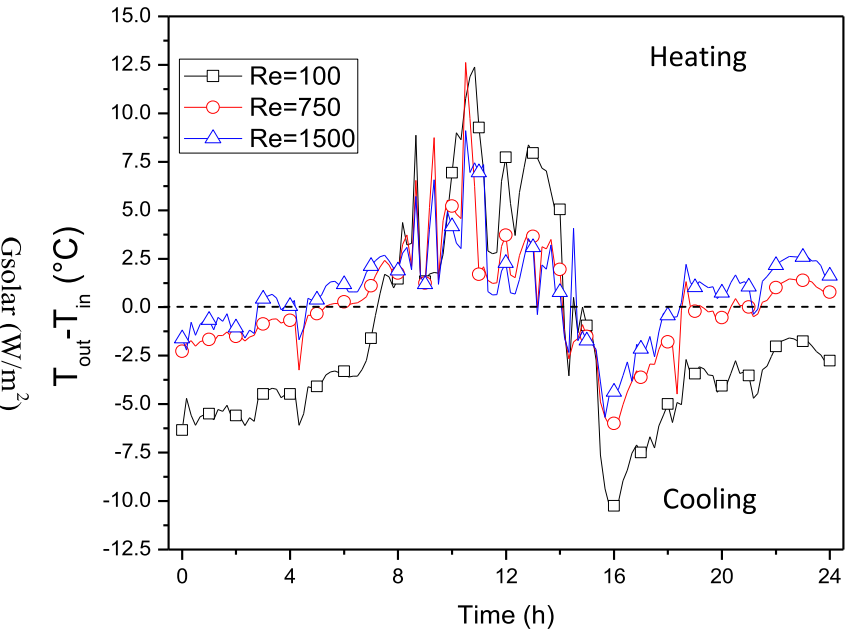

(b)

\section{Warmest day}

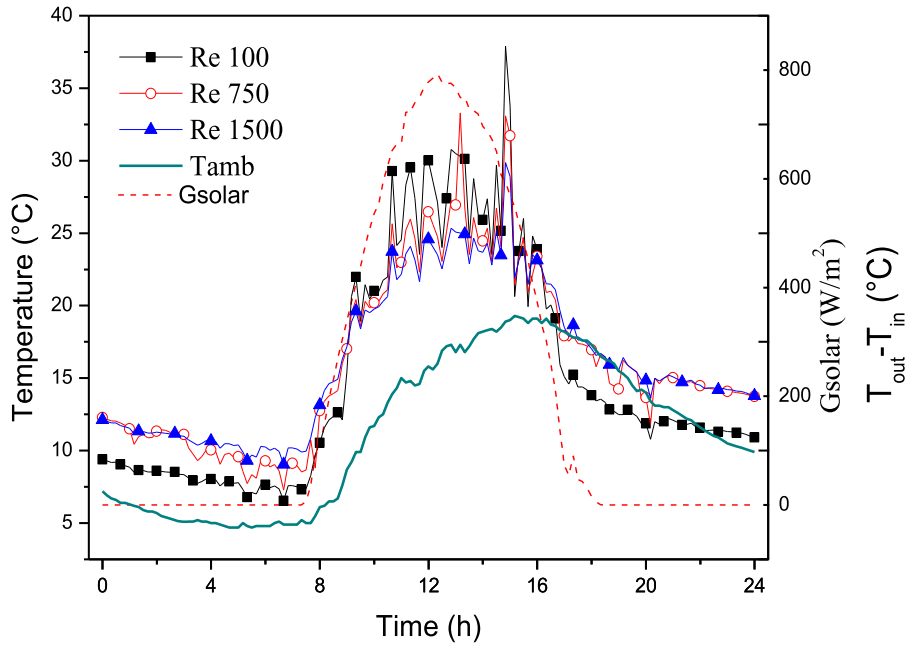

(c)

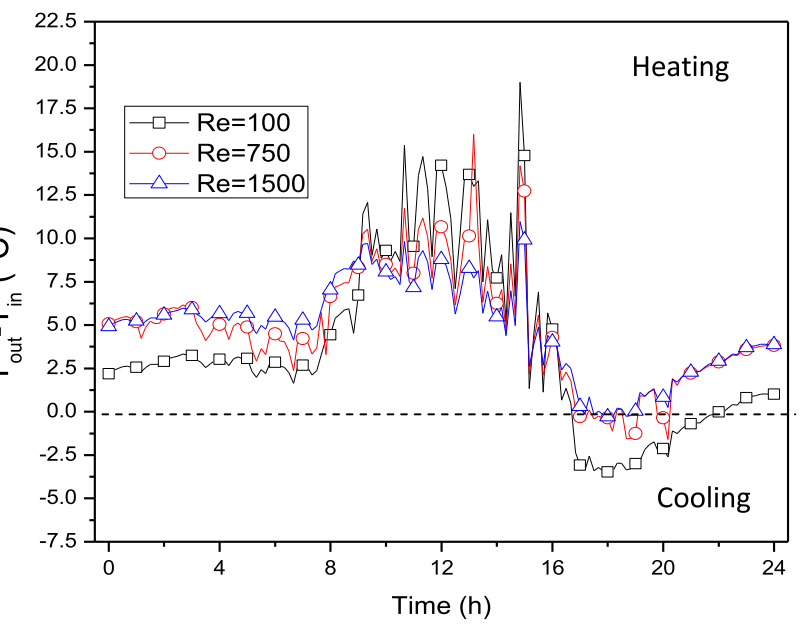

(d)

\section{Coldest day}

Fig. 8. Thermal behavior of the EAHE for the warmest and coldest day in Mexico City.

$(R e=1500)$. As the ambient temperature increases due to solar radiation so does the heating capacity of the EAHE, with the three Reynolds number close to each other. The maximum increment in the outlet temperature was $19^{\circ} \mathrm{C}$ at $15: 00 \mathrm{~h}$ for $R e=100$. After $14: 00 \mathrm{~h}$, as the ambient temperature decreases so does the heating capacity of the EAHE getting air outlet temperature similar to the ambient temperature and even lower for low Reynolds number $(R e=100)$.

\subsection{Mass flow rate and velocity}

Based on the previous results the best performance of the EAHE was achieve for a dry climate such as in Juarez City, while the less favorable performance was observed in hothumid climates such as in Villahermosa. In this section, velocities and mass flow rates at the outlet of the EAHE for Juarez City are shown. The mass flow and velocities of the other cities are omitted because those values are similar with respect to each other.

\subsubsection{Mass flow rate and velocity: Juarez City}

The air velocity for both, the warmest and coldest day in Juarez City show a relatively constant behavior throughout the day with values of $1.83 \times 10^{-5}, 2.72 \times 10^{-4}$, and $3.64 \times 10^{-3} \mathrm{~m} / \mathrm{s}$ for Reynolds number of 100,750 and 1500 , respectively. Although the air velocity remains almost constant, the velocity pattern at the outlet does 


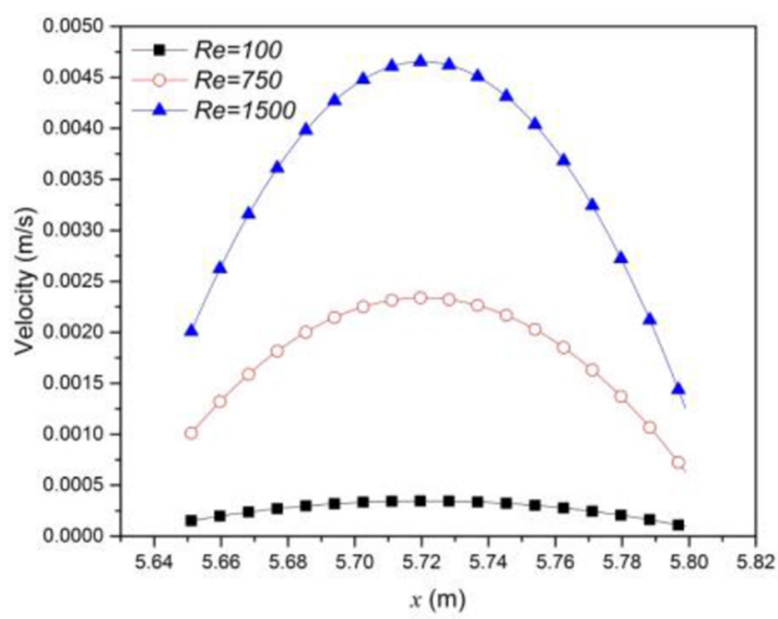

(a) warmest day

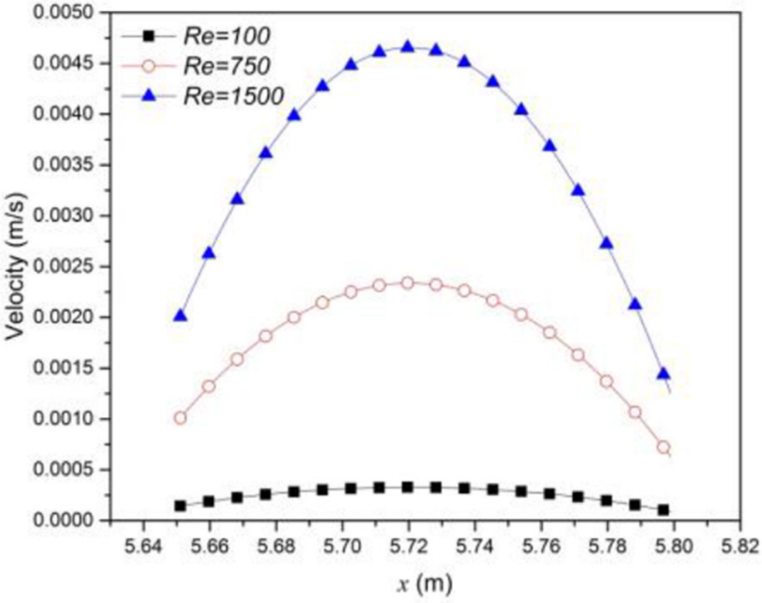

(b) coldest day

\section{Velocity profile}

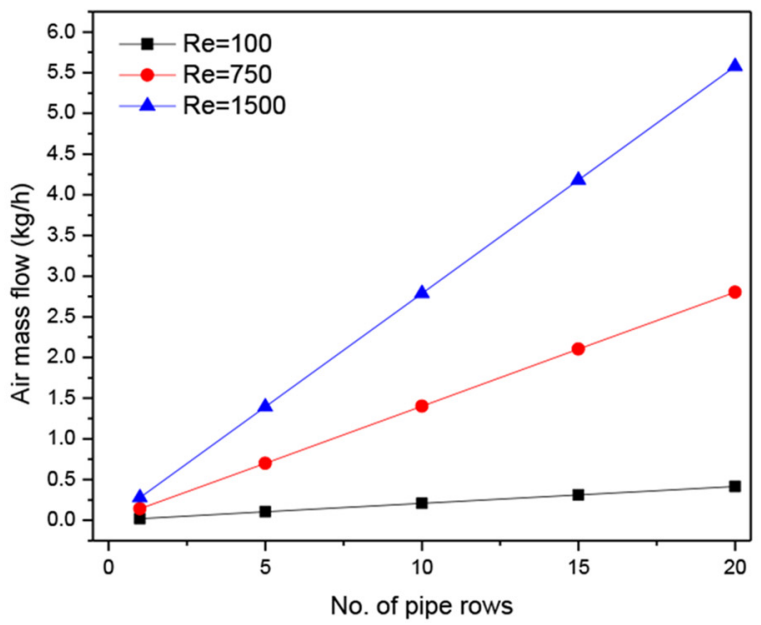

(c) warmest day

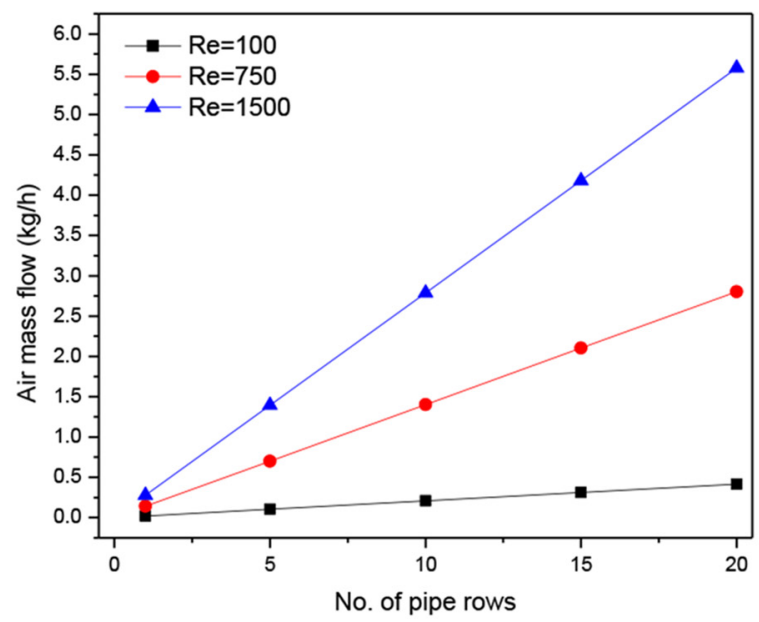

(d) coldest day

\section{Mass flow}

Fig. 9. Velocity profile and mass flow at the outlet of the EAHE in Juarez City.

change regarding the air velocity, shaping a more pronounced parabola as the air velocity increases as shown in Figure 9a and b. The maximum air velocity reached in the outlet of the EAHE was $4.65 \times 10^{-3} \mathrm{~m} / \mathrm{s}$ for a $R e=1500$.

The warmest day in Juarez City provides a mass flow rate of $0.02,0.14$ and $0.28 \mathrm{~kg} / \mathrm{h}$ for Reynolds number of 100,750 and 1500, respectively for one pipe; this value was very close for both, the warmest and the coldest day. Taking into account that this mas flow was achieved with one single pipe, any additional pipe added to the system should contribute in the same quantity, such that an increment on the air supplied to a room can be secure as shown in Figure $9 \mathrm{c}$ and d. Both graphs show that as the number of pipes increases so does the mass flow rate at the outlet of the system, especially for $R e=1500 \quad(5.6 \mathrm{~kg} / \mathrm{h})$ when implemented with twenty pipes.

\section{Concluding remarks}

A numerical study of a geothermal EAHE was carried out for six cities in Mexico, each city represents one of weathers in the country to evaluate the thermal performance under different climate conditions. The EAHE was analyzed for 
Table 4. Weather data for Villahermosa.

\begin{tabular}{|c|c|c|c|c|c|c|c|c|}
\hline \multirow[t]{2}{*}{ Time } & \multicolumn{4}{|c|}{ Warmest day (April 28 $\left.8^{\text {th }}\right)$} & \multicolumn{4}{|c|}{ Coldest day (February $\left.2^{\text {nd }}\right)$} \\
\hline & $\begin{array}{l}\text { Solar radiation } \\
\left(\mathrm{W} / \mathrm{m}^{2}\right)\end{array}$ & $T\left({ }^{\circ} \mathrm{C}\right)$ & $\mathrm{RH}(\%)$ & $\begin{array}{l}\text { Wind velocity } \\
(\mathrm{m} / \mathrm{s})\end{array}$ & $\begin{array}{l}\text { Solar radiation } \\
\left(\mathrm{W} / \mathrm{m}^{2}\right)\end{array}$ & $T\left({ }^{\circ} \mathrm{C}\right)$ & $\mathrm{RH}(\%)$ & $\begin{array}{l}\text { Wind velocity } \\
(\mathrm{m} / \mathrm{s})\end{array}$ \\
\hline 01:00 & 0 & 29.0 & 75 & 0.9 & 0 & 24.2 & 79 & 2.2 \\
\hline 02:00 & 0 & 28.6 & 75 & 0.9 & 0 & 23.1 & 86 & 2.2 \\
\hline 03:00 & 0 & 27.5 & 79 & 0.9 & 0 & 22.8 & 88 & 2.1 \\
\hline 04:00 & 0 & 27.9 & 77 & 1.8 & 0 & 22.2 & 91 & 1.3 \\
\hline 05:00 & 0 & 27.1 & 81 & 1.2 & 0 & 21.7 & 93 & 1 \\
\hline 06:00 & 0 & 26.8 & 83 & 1.3 & 0 & 21.2 & 94 & 0.9 \\
\hline 07:00 & 11 & 26.6 & 86 & 1.2 & 0 & 20.6 & 96 & 0.7 \\
\hline 08:00 & 125 & 27.4 & 83 & 1.8 & 13 & 20.8 & 94 & 0.6 \\
\hline 09:00 & 352 & 29.2 & 76 & 2.3 & 54 & 22.3 & 87 & 1.4 \\
\hline 10:00 & 567 & 31.3 & 69 & 1.4 & 413 & 24.8 & 78 & 1.6 \\
\hline 11:00 & 756 & 33.5 & 60 & 1 & 611 & 28.5 & 64 & 0.7 \\
\hline $12: 00$ & 851 & 35.2 & 56 & 0.8 & 763 & 28.6 & 65 & 2.6 \\
\hline 13:00 & 921 & 36.2 & 54 & 1.1 & 813 & 30.3 & 59 & 1.6 \\
\hline $14: 00$ & 943 & 38.2 & 44 & 1.4 & 748 & 30.4 & 59 & 2.5 \\
\hline 15:00 & 862 & 39 & 45 & 1.3 & 775 & 31.4 & 55 & 2.6 \\
\hline $16: 00$ & 663 & 38 & 45 & 2.8 & 636 & 31.8 & 55 & 2.8 \\
\hline 17:00 & 428 & 37.3 & 49 & 2.6 & 445 & 31.1 & 57 & 3.4 \\
\hline 18:00 & 219 & 36.5 & 48 & 1.8 & 52 & 29.9 & 65 & 3 \\
\hline 19:00 & 37 & 34.5 & 62 & 1.5 & 6 & 28.6 & 70 & 2.1 \\
\hline 20:00 & 0 & 33.4 & 65 & 1.5 & 0 & 27.3 & 74 & 1.8 \\
\hline 21:00 & 0 & 32 & 70 & 1.4 & 0 & 26.6 & 78 & 1.7 \\
\hline 22:00 & 0 & 30.6 & 75 & 1.2 & 0 & 26.2 & 78 & 2.5 \\
\hline 23:00 & 0 & 29.5 & 80 & 0.7 & 0 & 25.6 & 80 & 2.5 \\
\hline 24:00 & 0 & 29.3 & 81 & 0.6 & 0 & 25 & 83 & 1.4 \\
\hline
\end{tabular}

Table 5. Weather data for Mérida.

\begin{tabular}{|c|c|c|c|c|c|c|c|c|}
\hline \multirow[t]{2}{*}{ Time } & \multicolumn{4}{|c|}{ Warmest day $\left(\right.$ April $\left.7^{\text {th }}\right)$} & \multicolumn{4}{|c|}{ Coldest day (January $23^{\text {rd }}$ ) } \\
\hline & $\begin{array}{l}\text { Solar radiation } \\
\left(\mathrm{W} / \mathrm{m}^{2}\right)\end{array}$ & $T\left({ }^{\circ} \mathrm{C}\right)$ & $\mathrm{RH}(\%)$ & $\begin{array}{l}\text { Wind velocity } \\
(\mathrm{m} / \mathrm{s})\end{array}$ & $\begin{array}{l}\text { Solar radiation } \\
\left(\mathrm{W} / \mathrm{m}^{2}\right)\end{array}$ & $T\left({ }^{\circ} \mathrm{C}\right)$ & $\mathrm{RH}(\%)$ & $\begin{array}{l}\text { Wind velocity } \\
(\mathrm{m} / \mathrm{s})\end{array}$ \\
\hline 01:00 & 0 & 26.6 & 71 & 3.4 & 0 & 17.6 & 71.0 & 3.5 \\
\hline 02:00 & 0 & 25.8 & 79 & 3.8 & 0 & 17.1 & 73.0 & 3.3 \\
\hline 03:00 & 0 & 25.4 & 83 & 4 & 0 & 16.3 & 76.0 & 2.5 \\
\hline 04:00 & 0 & 25.3 & 85 & 3.9 & 0 & 16.3 & 76.0 & 2.6 \\
\hline 05:00 & 0 & 25.1 & 86 & 3.4 & 0 & 16.3 & 76.0 & 2.4 \\
\hline 06:00 & 0 & 24.8 & 88 & 3.5 & 0 & 16.2 & 76.0 & 2.8 \\
\hline 07:00 & 17 & 24.5 & 89 & 3.5 & 0 & 16.4 & 74.0 & 2.7 \\
\hline 08:00 & 192 & 26.2 & 81 & 4.7 & 50 & 16.7 & 73.0 & 2.2 \\
\hline 09:00 & 513 & 29.3 & 68 & 4.8 & 284 & 19.1 & 65.0 & 3.3 \\
\hline 10:00 & 715 & 31.5 & 58 & 5.4 & 512 & 21.8 & 58.0 & 4.1 \\
\hline 11:00 & 885 & 34.6 & 47 & 4.5 & 686 & 24.8 & 51.0 & 3.4 \\
\hline $12: 00$ & 986 & 36.3 & 41 & 3.6 & 794 & 26.1 & 46.0 & 3.5 \\
\hline 13:00 & 999 & 37.9 & 34 & 2.9 & 821 & 27.1 & 44.0 & 3.1 \\
\hline
\end{tabular}


Table 5. (continued).

\begin{tabular}{|c|c|c|c|c|c|c|c|c|}
\hline \multirow[t]{2}{*}{ Time } & \multicolumn{4}{|c|}{ Warmest day (April $\left.7^{\text {th }}\right)$} & \multicolumn{4}{|c|}{ Coldest day (January $23^{\text {rd }}$ ) } \\
\hline & $\begin{array}{l}\text { Solar radiation } \\
\left(\mathrm{W} / \mathrm{m}^{2}\right)\end{array}$ & $T\left({ }^{\circ} \mathrm{C}\right)$ & $\mathrm{RH}(\%)$ & $\begin{array}{l}\text { Wind velocity } \\
(\mathrm{m} / \mathrm{s})\end{array}$ & $\begin{array}{l}\text { Solar radiation } \\
\left(\mathrm{W} / \mathrm{m}^{2}\right)\end{array}$ & $T\left({ }^{\circ} \mathrm{C}\right)$ & $\mathrm{RH}(\%)$ & $\begin{array}{l}\text { Wind velocity } \\
(\mathrm{m} / \mathrm{s})\end{array}$ \\
\hline 14:00 & 959 & 39.2 & 28 & 1.5 & 791 & 27.5 & 41.0 & 3.2 \\
\hline 15:00 & 845 & 39.9 & 26 & 1.5 & 678 & 28.4 & 39.0 & 2.8 \\
\hline 16:00 & 619 & 41.5 & 24 & 1.4 & 529 & 28.8 & 39.0 & 3.3 \\
\hline 17:00 & 389 & 40.3 & 25 & 2.2 & 296 & 28.5 & 39.0 & 2.8 \\
\hline 18:00 & 192 & 37.9 & 33 & 4.2 & 45 & 25.0 & 56.0 & 4.1 \\
\hline 19:00 & 9 & 32.2 & 61 & 5 & 0 & 23.5 & 62.0 & 4.0 \\
\hline 20:00 & 0 & 29.8 & 72 & 3.2 & 0 & 22.8 & 66.0 & 4.2 \\
\hline 21:00 & 0 & 28.6 & 78 & 3.5 & 0 & 22.4 & 72.0 & 3.7 \\
\hline 22:00 & 0 & 28.2 & 79 & 3 & 0 & 22.0 & 74.0 & 3.7 \\
\hline 23:00 & 0 & 28 & 78 & 2 & 0 & 21.6 & 76.0 & 4.4 \\
\hline 24:00 & 0 & 28.2 & 77 & 2.4 & 0 & 21.4 & 75.0 & 4.3 \\
\hline
\end{tabular}

Table 6. Weather data for Juárez City.

\begin{tabular}{|c|c|c|c|c|c|c|c|c|}
\hline \multirow[t]{2}{*}{ Time } & \multicolumn{4}{|c|}{ Warmest day (April $\left.27^{\text {th }}\right)$} & \multicolumn{4}{|c|}{ Coldest day (February $8^{\text {th }}$ ) } \\
\hline & $\begin{array}{l}\text { Solar radiation } \\
\left(\mathrm{W} / \mathrm{m}^{2}\right)\end{array}$ & $T\left({ }^{\circ} \mathrm{C}\right)$ & $\mathrm{RH}(\%)$ & $\begin{array}{l}\text { Wind velocity } \\
(\mathrm{m} / \mathrm{s})\end{array}$ & $\begin{array}{l}\text { Solar radiation } \\
\left(\mathrm{W} / \mathrm{m}^{2}\right)\end{array}$ & $T\left({ }^{\circ} \mathrm{C}\right)$ & $\mathrm{RH}(\%)$ & $\begin{array}{l}\text { Wind velocity } \\
(\mathrm{m} / \mathrm{s})\end{array}$ \\
\hline 01:00 & 0 & 34.3 & 17 & 3.1 & 0 & 0.1 & 45 & 0 \\
\hline 02:00 & 0 & 33.5 & 17 & 3.6 & 0 & 1.3 & 40 & 1.6 \\
\hline 03:00 & 0 & 32.6 & 18 & 3.3 & 0 & 0.1 & 44 & 0.9 \\
\hline 04:00 & 0 & 32.2 & 19 & 4 & 0 & -0.2 & 41 & 1.4 \\
\hline 05:00 & 0 & 30.1 & 23 & 1.1 & 0 & -0.5 & 38 & 1.1 \\
\hline 06:00 & 0 & 29.4 & 23 & 2 & 0 & 0.3 & 33 & 1.8 \\
\hline 07:00 & 0 & 28.3 & 25 & 2.6 & 0 & -1 & 40 & 1.3 \\
\hline 08:00 & 28 & 28.1 & 26 & 2.2 & 0 & -2.2 & 44 & 0.8 \\
\hline 09:00 & 52 & 30.2 & 21 & 3.7 & 2 & -2.7 & 44 & 1.5 \\
\hline 10:00 & 493 & 31 & 20 & 5.1 & 31 & -1.7 & 40 & 1.2 \\
\hline 11:00 & 687 & 33.2 & 17 & 4.5 & 358 & 0.7 & 29 & 3.5 \\
\hline $12: 00$ & 850 & 35.9 & 13 & 3.8 & 546 & 3.5 & 24 & 3.1 \\
\hline $13: 00$ & 971 & 39.3 & 10 & 2.8 & 680 & 5.8 & 21 & 2.3 \\
\hline $14: 00$ & 1039 & 41 & 7 & 3.4 & 751 & 7.9 & 18 & 1.2 \\
\hline $15: 00$ & 1030 & 42.5 & 6 & 2.7 & 752 & 9.4 & 16 & 1.1 \\
\hline $16: 00$ & 961 & 45.4 & 6 & 1.9 & 688 & 9.2 & 16 & 1.8 \\
\hline $17: 00$ & 849 & 45.1 & 7 & 2.1 & 554 & 10.5 & 13 & 1.8 \\
\hline 18:00 & 659 & 44.4 & 6 & 2.6 & 365 & 10.8 & 13 & 1.3 \\
\hline 19:00 & 447 & 44.8 & 6 & 1.8 & 135 & 8.4 & 16 & 1.2 \\
\hline 20:00 & 220 & 42.8 & 6 & 2.4 & 0 & 7 & 16 & 0.9 \\
\hline 21:00 & 7 & 39.9 & 8 & 3 & 0 & 5.9 & 18 & 0.8 \\
\hline $22: 00$ & 0 & 36.8 & 11 & 1.2 & 0 & 5 & 22 & 0.9 \\
\hline $23: 00$ & 0 & 33.6 & 16 & 0.8 & 0 & 2.9 & 30 & 0.7 \\
\hline 24:00 & 0 & 35 & 12 & 2.2 & 0 & 3.8 & 29 & 1.4 \\
\hline
\end{tabular}


Table 7. Weather data for Monterrey.

\begin{tabular}{|c|c|c|c|c|c|c|c|c|}
\hline \multirow[t]{2}{*}{ Time } & \multicolumn{4}{|c|}{ Warmest day $\left(\right.$ April $\left.27^{\text {th }}\right)$} & \multicolumn{4}{|c|}{ Coldest day (February $8^{\text {th }}$ ) } \\
\hline & $\begin{array}{l}\text { Solar radiation } \\
\left(\mathrm{W} / \mathrm{m}^{2}\right)\end{array}$ & $T\left({ }^{\circ} \mathrm{C}\right)$ & $\mathrm{RH}(\%)$ & $\begin{array}{l}\text { Wind velocity } \\
(\mathrm{m} / \mathrm{s})\end{array}$ & $\begin{array}{l}\text { Solar radiation } \\
\left(\mathrm{W} / \mathrm{m}^{2}\right)\end{array}$ & $T\left({ }^{\circ} \mathrm{C}\right)$ & $\mathrm{RH}(\%)$ & $\begin{array}{l}\text { Wind velocity } \\
(\mathrm{m} / \mathrm{s})\end{array}$ \\
\hline 01:00 & 0 & 28.2 & 49 & 2.3 & 0 & 6.0 & 95.0 & 1.6 \\
\hline 02:00 & 0 & 26.1 & 57 & 2 & 0 & 5.3 & 96.0 & 1.2 \\
\hline 03:00 & 0 & 24.3 & 63 & 1.2 & 0 & 5.5 & 96.0 & 0.9 \\
\hline 04:00 & 0 & 24.2 & 65 & 0.9 & 0 & 5.5 & 96.0 & 0.6 \\
\hline 05:00 & 0 & 24.2 & 67 & 2 & 0 & 6.0 & 96.0 & 0.0 \\
\hline 06:00 & 0 & 24.2 & 64 & 1.5 & 0 & 6.2 & 93.0 & 0.7 \\
\hline 07:00 & 0 & 23.6 & 64 & 0.7 & 0 & 6.3 & 91.0 & 0.9 \\
\hline 08:00 & 96 & 28.6 & 35 & 1.5 & 0 & 5.9 & 94.0 & 1.3 \\
\hline 09:00 & 287 & 32.2 & 19 & 2.5 & 52 & 6.0 & 93.0 & 1.4 \\
\hline 10:00 & 500 & 34.2 & 17 & 6.8 & 244 & 10.4 & 71.0 & 1.8 \\
\hline 11:00 & 722 & 35.8 & 16 & 6.4 & 439 & 10.9 & 71.0 & 2.9 \\
\hline 12:00 & 876 & 37.5 & 14 & 6.2 & 610 & 12.3 & 68.0 & 1.9 \\
\hline 13:00 & 962 & 38.2 & 13 & 7 & 715 & 16.1 & 55.0 & 2.1 \\
\hline 14:00 & 973 & 40.2 & 11 & 5.7 & 766 & 17.4 & 52.0 & 2.4 \\
\hline 15:00 & 889 & 40.9 & 11 & 6.4 & 706 & 19.3 & 44.0 & 3.2 \\
\hline $16: 00$ & 782 & 41.6 & 9 & 4.2 & 601 & 19.5 & 49.0 & 3.9 \\
\hline 17:00 & 590 & 41.2 & 10 & 4.5 & 412 & 18.9 & 54.0 & 4.0 \\
\hline 18:00 & 387 & 40.3 & 12 & 2.8 & 213 & 16.6 & 63.0 & 3.7 \\
\hline 19:00 & 179 & 37.7 & 16 & 2.9 & 25 & 15.0 & 68.0 & 3.0 \\
\hline 20:00 & 8 & 35.8 & 19 & 3.5 & 0 & 13.1 & 76.0 & 2.6 \\
\hline 21:00 & 0 & 33.7 & 22 & 3 & 0 & 12.2 & 80.0 & 2.3 \\
\hline 22:00 & 0 & 32.2 & 23 & 1.5 & 0 & 10.4 & 85.0 & 2.1 \\
\hline 23:00 & 0 & 31.1 & 24 & 2.2 & 0 & 9.1 & 90.0 & 1.6 \\
\hline 24:00 & 0 & 30.4 & 23 & 3 & 0 & 8.7 & 92.0 & 1.2 \\
\hline
\end{tabular}

Table 8. Weather data for Zacualtipan-Hidalgo.

\begin{tabular}{|c|c|c|c|c|c|c|c|c|}
\hline \multirow[t]{2}{*}{ Time } & \multicolumn{4}{|c|}{ Warmest day $\left(\right.$ April $\left.1^{\text {st }}\right)$} & \multicolumn{4}{|c|}{ Coldest day (January $23^{\text {rd }}$ ) } \\
\hline & $\begin{array}{l}\text { Solar radiation } \\
\left(\mathrm{W} / \mathrm{m}^{2}\right)\end{array}$ & $T\left({ }^{\circ} \mathrm{C}\right)$ & $\mathrm{RH}(\%)$ & $\begin{array}{l}\text { Wind velocity } \\
(\mathrm{m} / \mathrm{s})\end{array}$ & $\begin{array}{l}\text { Solar radiation } \\
\left(\mathrm{W} / \mathrm{m}^{2}\right)\end{array}$ & $T\left({ }^{\circ} \mathrm{C}\right)$ & $\mathrm{RH}(\%)$ & $\begin{array}{l}\text { Wind velocity } \\
(\mathrm{m} / \mathrm{s})\end{array}$ \\
\hline 01:00 & 0 & 24.2 & 34 & 3.8 & 0 & 4.5 & 77 & 1.5 \\
\hline 02:00 & 0 & 22.9 & 36 & 2.8 & 0 & 4.5 & 78 & 1.4 \\
\hline 03:00 & 0 & 22.4 & 37 & 3.3 & 0 & 4.4 & 78 & 1.3 \\
\hline 04:00 & 0 & 21.8 & 37 & 4.3 & 0 & 3.8 & 78 & 1.1 \\
\hline 05:00 & 0 & 20.9 & 38 & 3.8 & 0 & 3.6 & 78 & 1.3 \\
\hline 06:00 & 0 & 20.7 & 36 & 4 & 0 & 3.4 & 78 & 1.6 \\
\hline 07:00 & 0 & 19.1 & 39 & 1.9 & 0 & 3.1 & 78 & 1.4 \\
\hline 08:00 & 14 & 19 & 39 & 4.2 & 0 & 2.9 & 78 & 1.6 \\
\hline 09:00 & 37 & 19.6 & 39 & 4.6 & 29 & 3.5 & 78 & 1.4 \\
\hline 10:00 & 590 & 25.9 & 28 & 8.9 & 382 & 12.4 & 73 & 1.5 \\
\hline 11:00 & 812 & 27.2 & 27 & 8.4 & 605 & 15 & 53 & 2.7 \\
\hline 12:00 & 975 & 29.3 & 25 & 8.9 & 773 & 14.5 & 56 & 7.4 \\
\hline $13: 00$ & 1073 & 30.8 & 23 & 8.1 & 884 & 14.8 & 58 & 6.8 \\
\hline 14:00 & 1084 & 32.5 & 22 & 6.8 & 914 & 15.9 & 56 & 5.9 \\
\hline $15: 00$ & 1027 & 32.4 & 21 & 9 & 859 & 15.6 & 56 & 9.4 \\
\hline
\end{tabular}


Table 8. (continued).

\begin{tabular}{|c|c|c|c|c|c|c|c|c|}
\hline \multirow[t]{2}{*}{ Time } & \multicolumn{4}{|c|}{ Warmest day (April $1^{\text {st }}$ ) } & \multicolumn{4}{|c|}{ Coldest day (January $23^{\text {rd }}$ ) } \\
\hline & $\begin{array}{l}\text { Solar radiation } \\
\left(\mathrm{W} / \mathrm{m}^{2}\right)\end{array}$ & $T\left({ }^{\circ} \mathrm{C}\right)$ & $\mathrm{RH}(\%)$ & $\begin{array}{l}\text { Wind velocity } \\
(\mathrm{m} / \mathrm{s})\end{array}$ & $\begin{array}{l}\text { Solar radiation } \\
\left(\mathrm{W} / \mathrm{m}^{2}\right)\end{array}$ & $T\left({ }^{\circ} \mathrm{C}\right)$ & $\mathrm{RH}(\%)$ & $\begin{array}{l}\text { Wind velocity } \\
(\mathrm{m} / \mathrm{s})\end{array}$ \\
\hline 16:00 & 916 & 33.3 & 20 & 6.7 & 734 & 15.4 & 59 & 7.2 \\
\hline 17:00 & 404 & 32.4 & 20 & 6.4 & 526 & 15.4 & 59 & 6.5 \\
\hline 18:00 & 178 & 28.1 & 34 & 3.6 & 58 & 12.9 & 66 & 6.2 \\
\hline 19:00 & 63 & 25.4 & 56 & 3.1 & 22 & 11.1 & 72 & 4 \\
\hline 20:00 & 0 & 24.8 & 42 & 1.5 & 0 & 10 & 77 & 3.2 \\
\hline 21:00 & 0 & 21.7 & 53 & 5 & 0 & 9.2 & 78 & 2.3 \\
\hline 22:00 & 0 & 20.7 & 73 & 10.4 & 0 & 6.8 & 78 & 2.3 \\
\hline 23:00 & 0 & 19.2 & 75 & 5.5 & 0 & 6.2 & 78 & 1.6 \\
\hline 24:00 & 0 & 18.1 & 81 & 6.8 & 0 & 5.8 & 78 & 1.6 \\
\hline
\end{tabular}

Table 9. Weather data for Mexico City.

\begin{tabular}{|c|c|c|c|c|c|c|c|c|}
\hline \multirow[t]{2}{*}{ Time } & \multicolumn{4}{|c|}{ Warmest day (March $\left.14^{\text {th }}\right)$} & \multicolumn{4}{|c|}{ Coldest day (January $\left.18^{\text {th }}\right)$} \\
\hline & $\begin{array}{l}\text { Solar radiation } \\
\left(\mathrm{W} / \mathrm{m}^{2}\right)\end{array}$ & $T\left({ }^{\circ} \mathrm{C}\right)$ & $\mathrm{RH}(\%)$ & $\begin{array}{l}\text { Wind velocity } \\
(\mathrm{m} / \mathrm{s})\end{array}$ & $\begin{array}{l}\text { Solar radiation } \\
\left(\mathrm{W} / \mathrm{m}^{2}\right)\end{array}$ & $T\left({ }^{\circ} \mathrm{C}\right)$ & $\mathrm{RH}(\%)$ & $\begin{array}{l}\text { Wind velocity } \\
(\mathrm{m} / \mathrm{s})\end{array}$ \\
\hline 01:00 & 0 & 21.7 & 37 & 0.6 & 0 & 7.2 & 56 & 1.4 \\
\hline 02:00 & 0 & 21 & 36 & 1.3 & 0 & 6.3 & 57 & 1.4 \\
\hline 03:00 & 0 & 20.1 & 38 & 0.6 & 0 & 5.7 & 55 & 1.7 \\
\hline 04:00 & 0 & 19.9 & 43 & 1.3 & 0 & 5.1 & 60 & 1.8 \\
\hline 05:00 & 0 & 19.1 & 44 & 0.8 & 0 & 5 & 60 & 1.2 \\
\hline 06:00 & 0 & 18.5 & 46 & 0.8 & 0 & 4.7 & 65 & 0.9 \\
\hline 07:00 & 0 & 17.7 & 48 & 1.2 & 0 & 4.8 & 61 & 0.8 \\
\hline 08:00 & 92 & 18 & 46 & 0.1 & 0 & 4.9 & 60 & 0.7 \\
\hline 09:00 & 333 & 22 & 34 & 0.6 & 109 & 6.1 & 57 & 0.5 \\
\hline 10:00 & 562 & 24.1 & 28 & 1.3 & 338 & 8.7 & 50 & 0.6 \\
\hline 11:00 & 751 & 25.5 & 27 & 0.3 & 537 & 11.7 & 40 & 0.8 \\
\hline $12: 00$ & 866 & 26.5 & 24 & 0 & 666 & 15 & 26 & 0.8 \\
\hline 13:00 & 1011 & 27.7 & 19 & 1.1 & 778 & 15.8 & 21 & 0.5 \\
\hline $14: 00$ & 947 & 28.5 & 17 & 0.9 & 767 & 16.8 & 24 & 0.5 \\
\hline 15:00 & 918 & 29.2 & 16 & 1.1 & 696 & 18.2 & 23 & 0.9 \\
\hline $16: 00$ & 796 & 30.5 & 16 & 1.7 & 569 & 19 & 22 & 0.1 \\
\hline $17: 00$ & 33 & 28.7 & 17 & 1.2 & 373 & 19.1 & 22 & 0.3 \\
\hline $18: 00$ & 1 & 24.8 & 26 & 2.9 & 74 & 18.2 & 23 & 1.6 \\
\hline 19:00 & 0 & 21.4 & 31 & 3 & 16 & 17.3 & 26 & 0.9 \\
\hline 20:00 & 0 & 19.4 & 49 & 2.2 & 0 & 15.5 & 32 & 0.5 \\
\hline 21:00 & 0 & 19.4 & 45 & 1.4 & 0 & 14 & 36 & 0.5 \\
\hline $22: 00$ & 0 & 18.3 & 50 & 1 & 0 & 12.8 & 37 & 1.8 \\
\hline 23:00 & 0 & 17.4 & 57 & 2.5 & 0 & 11.6 & 40 & 1.9 \\
\hline 24:00 & 0 & 16.4 & 52 & 4.3 & 0 & 10.5 & 46 & 2.3 \\
\hline
\end{tabular}

the coldest and warmest day in each city and three different Reynolds numbers (100, 750 and 1500). From the numerical results, we conclude that:

The maximum ventilation potential on the warm day was obtained in the cities of Monterrey, Nuevo León and
Cd. Juárez, Chihuahua (dry climates), with a maximum temperature decrease of 17.6 and $18.5{ }^{\circ} \mathrm{C}$ respectively. While the maximum temperature increase in the cold day is 9.7 and $13.3^{\circ} \mathrm{C}$ in Monterrey, Nuevo León and Cd. Juárez, Chihuahua, respectively. 
The cities of Villahermosa, Tabasco and Merida, Yucatan (warm climates) had an air temperature decrease on the warmest day of 8.9 and $13.3^{\circ} \mathrm{C}$, respectively. On the other hand, the increase in air temperature on the coldest day was 6.2 and $3.2{ }^{\circ} \mathrm{C}$ for Villahermosa, Tabasco and Merida, Yucatan respectively, being the Villahermosa the one with lowest heating potential compared to the other cities. However, a maximum decrease in air temperature of $5{ }^{\circ} \mathrm{C}$ was observed in both towns during the hours with solar irradiance, which is beneficial because both types of weather exceeded $30^{\circ} \mathrm{C}$ during most of the day, even in the cold season. In this case, it was the city of Merida, Yucatan that presented a better thermal performance than the City of Villahermosa, Tabasco, having a lower level of humidity in the air.

Finally, in the cities of Zacualtipan, Hidalgo and Mexico City (temperate climates), a maximum decrease in air temperature of 12.6 and $10.2^{\circ} \mathrm{C}$ was obtained on the warmest day, with thermal performance very similar to the that of a city with a warm climate. However, the increase in air temperature in the coldest day is 8.2 and $19^{\circ} \mathrm{C}$ in the cities of Zacualtipan, Hidalgo and Mexico City respectively, this increase is better than that of warm climates and very similar to that of dry climates.

\section{Nomenclature}

$C_{p} \quad$ Specific heat $\mathrm{J} / \mathrm{kg} \mathrm{K}$

$f \quad$ A fraction which depends mainly on the ground cover and on the humidity level of the ground, dimensionless

$G_{\text {solar }}$ Solar radiation, $\mathrm{W} / \mathrm{m}^{2}$

$h$ Convective heat transfer coefficient, $\mathrm{W} / \mathrm{m}^{2} \mathrm{~K}$

RH Relativity humidity

$P \quad$ Pressure, $\mathrm{Pa}$

$Q \quad$ Heat flux, $\mathrm{W} / \mathrm{m}^{2}$

Re Reynolds number, adimensional

$T \quad$ Temperature, ${ }^{\circ} \mathrm{C}$

$T_{i n} \quad$ Air temperature at the inlet, ${ }^{\circ} \mathrm{C}$

$T_{\text {out }} \quad$ Air temperature at the outlet, ${ }^{\circ} \mathrm{C}$

$u \quad$ Component of velocity in $x$ direction, $\mathrm{m} / \mathrm{s}$

$v \quad$ Component of velocity in $y$ direction, $\mathrm{m} / \mathrm{s}$

$x \quad$ Coordinate in horizontal direction, $m$

$y \quad$ Coordinate in vertical direction $m$

Greek letters

$\alpha$ Absorptivity, dimensionless

$\varepsilon \quad$ Emittance of the soil surface

$\lambda$ Thermal conductivity, $\mathrm{W} / \mathrm{m} \mathrm{K}$

$\mu$ Dynamic viscosity, $\mathrm{kg} \mathrm{m}^{-1} \mathrm{~s}^{-1}$

$\rho$ Density, $\mathrm{kg} \mathrm{m}^{-3}$

Subscripts

amb Ambient

ave Average

cond Conduction heat tranfers

conv Convection heat transfer
C Cool wall

evap Evaporation in the surface of the ground

$H \quad$ Hot wall

rad Radiation heat transfer

sur Surface

M. Rodríguez-Vázquez acknowledges the support provided by the Consejo Nacional de Ciencia y Tecnología (CONACYT) given through its doctorate scholarship program.

\section{References}

[1] K.K. Agrawal, R. Misra, T. Yadav, G.D. Agrawal, D.J. Jamuwa, Experimental study to investigate the effect of water impregnation on thermal performance of earth air tunnel heat exchanger for summer cooling in hot and arid climate, Renew. Energy 120, 255-265 (2018)

[2] N.A.S. Elminshawy, F.R. Siddiqui, Q.U. Farooq, M.F. Addas, Experimental investigation on the performance of earth-air pipe heat exchanger for different soil compaction levels, Appl. Therm. Eng. 124, 1319-1327 (2017)

[3] S.K. Soni, M. Pandey, V.N. Bartaria, Experimental analysis of a direct expansion ground coupled heat exchange system for space cooling requirements, Energy Build. 119, 85-92 (2016)

[4] D. Yang, J. Zhang, Analysis and experiments on the periodically fluctuating air temperature in a building with earth air tube ventilation, Build. Environ. 85, 29-39 (2015)

[5] H. Breesch, A. Bossaer, A. Janssens, Passive cooling in a lowenergy office building, Solar Energy 79, 682-696 (2005)

[6] F. Fazlikhani, H. Goudarzi, E. Solgi, Numerical analysis of the efficiency of earth to air heat exchanger system in cold and hot-arid climates, Energy Convers. Manag. 148, 78-98 (2017)

[7] J. Pfafferott, Evaluation of earth-to-air heat exchangers with standardized method to calculate energy efficiency, Energy Build. 35, 971-983 (2003)

[8] K. Voss, S. Herkel, J. Pfafferott, G. Lonnart, A. Wangner, Energy efficient office buildings with passive-result and experiences from a research and demonstration program, Solar Energy 81, 424-434 (2007)

[9] D. Yang, Y. Gou, J. Zhang, Evaluation of thermal performance of an earth to-air heat exchanger (EAHE) in harmonic thermal environment, Energy Convers. Manag. 109, 184-194 (2016)

[10] C.E. Mehdid, A. Benchabane, A. Rouag, N. Moummi, M.A. Melhegueg, A. Moummi, M.L. Benabdi, A. Brima, Thermal design of Earth-to-air heat exchanger. Part II a new transientsemi-analytical model and experimental validation for estimating air temperature, J. Cleaner Prod. 198, 1536-1544 (2018)

[11] L. Amanowicz, J. Wojtkowiak, Validation of CFD model for simulation of multi-pipe earth-to-air heat exchanger (EAHEs) flow performance, Thermal Sci. Eng. Prog. 5, 44-49 (2018)

[12] K.K. Agrawal, M. Bhardwaj, R. Misra, G.D. Agrawal, V. Bansal, Optimization of operating parameters of earth air tunnel heat exchangers for space cooling: Taguchi method approach, Geotherm. Energy 6, 1-17 (2018) 
[13] S.F. Ahmed, M.T.O. Amanullah, M.M.K. Khan, M.G. Rasul, N.M.S. Hassan, Parametric study on thermal performance of horizontal earth pipe cooling system in summer, Energy Convers. Manag. 114, 324-337 (2010)

[14] T.S. Bisoniya, Design of an earth-air heat exchanger system, Geotherm. Energy 3, 1-10 (2015)

[15] T.S. Bisoniya, A. Kumar, P. Barender, Energy metrics of earth-air heat exchanger system for hot and dry climatic condition of India, Energy Build. 86, 214-221 (2015)

[16] M. Benhammou, B. Draoui, M. Hamouda, Improvement of the summer cooling induced by an earth-to-air heat exchanger integrated in a residential building under hot and arid climate, Appl. Energy 208, 428-445 (2017)

[17] R.S. Brum, J.V.A. Ramalho, M.K. Rodrigues, L.A.O. Rocha, I. LiéA, E.D. Dos Santos, Design evaluation of earth-air heat exchangers with multiple ducts, Renew. Energy https://doi.org/10.1016/j.renene.2018.09.063

[18] E. Estrada, M. Labat, S. Lorente, L.A.O. Rocha, The impact of latent heat exchanges on the design of earth air heat exchangers, Appl. Therm. Eng. 129, 306-317 (2018)

[19] N. Jamshidia, A. Mosaffab, Investigating the effects of geometric parameters on finned conical helical geothermal heat exchanger and its energy extraction capability, Geothermics 76, 177-189 (2018)

[20] N. Rosa, P. Santos, J.J. Costa, H. Gervásio, Modelling and performance analysis of an earth-to-air heat exchanger in a pilot installation, J. Build. Phys. 00, 1-29 (2018)

[21] F. Tasdelen, I. Dagtekin, A numerical investigation of thermal performance of earth-air heat exchanger, Arab. J. Sci. Eng. 44, 1151-1163 (2019)

[22] X. Wang, B.S. Bjerg, G. Zhang, Design-oriented modelling on cooling performance of the earth-air heat exchanger for livestock housing, Comput. Electr. Agric. 152, 51-58 (2018)

[23] J. Xamán, I. Hernández-Pérez, J. Arce, G. Álvarez, L. Ramírez-Davíla, F. Noh-Pat, Numerical study of earth to air heat exchanger: the effect of thermal insulation, Energy Build 85, 356-361 (2014)

[24] J. Xamán, I. Hernández-López, R. Alvarado-Juárez, I. Hernández-Pérez, G. Álvarez, Y. Chávez, Pseudo transient numerical study of the earth to air heat exchanger for different climates for México, Energy Build. 99, 273-283 (2015)

[25] M. Cuny, J. Lin, M. Siroux, V. Magnenet, C. Fond, Influence of coating soil types on the energy of earth-air heat exchanger, Energy Build. 158, 1000-1012 (2018)

[26] A. Mathur, A. Srivastava, G.D. Agrawal, S. Mathu, J. Mathur, CFD analysis of EATHE system under transient conditions for intermittent operation, Energy Build. 87, 37-44 (2015)

[27] A. Mathur, A.K. Surana, S. Mathur, Numerical investigation of the performance and soil temperature recovery of an EATHE system under intermittent operations, Renew. Energy 95, 510-521 (2016)

[28] R. Misra, S. Jakhar, K.K. Agrawal, S. Sharma, D.K. Jamuwa, M.S. Soni, G.D. Agrawal, Field investigations to determine the thermal performance of earth air tunnel heat exchanger with dry and wet soil: energy and exergetic analysis, Energy Build. 171, 107-115 (2018)

[29] F. Niu, Y. Yu, D. Yu, H. Li, Investigation on soil thermal saturation and recovery of an earth to air heat exchanger under different operation strategies, Appl. Thermal Eng. 77, 90-100 (2015)
[30] L. Ramirez-Davila, J. Xamán, J. Arce, G. Alvarez, I. Hernández-Pérez, Numerical study of earth-to-air heat exchanger for three different climates, Energy Build. $\mathbf{7 6}$ 238-248 (2015)

[31] M.K. Rodrigues, F.S. Coswig, K.R. Camargo, L.A. Isoldi, R. S. Brum, J.V.A. Ramalho, J. Vaz, L.A.O. Rocha, E.D. dos Santos, Thermal performance simulations of earth-air heat exchangers for different soils of a coastal city using in-situ data, Sustain. Energy Technol. Assess. 30, 224-229 (2018)

[32] M. Rodríguez-Vázquez, I. Hernández-Pérez, J. Xamán, Y. Chávez, F. Noh-Pat, Computational fluid dynamics for thermal evaluation of earth-to-air heat exchanger for different climates of Mexico, Techniques and ThermoMechanics Applications CFD in Driss, et al. (1 $\left.{ }^{\text {st }}\right)$ (2018) $33-51$

[33] A. Rouag, A. Benchabane, C.E. Mehdid, Thermal design of earth-to-air heat exchanger. Part I A new transient semianalytical model for determining soil temperature, J. Clean. Prod. 182, 538-544 (2018)

[34] R. Hassanzadeh, M. Darvishyadegari, S. Arman, A new idea for improving the horizontal straight ground source heat exchangers performance, Sustain. Energy Technolog. Assess. 25, 138-145 (2018)

[35] C.Y. Hsu, Y.C. Chiang, Z.J. Chien, S.L. Chen, Investigation on performance of building-integrated earth-air heat exchanger, Energy Build. 169, 444-452 (2018)

[36] M. Kaushal, P. Dhiman, S. Singh, H. Patel, Finite volume and response surface methodology based performance prediction and optimization of a hybrid earth to air tunnel heat exchanger, Energy Build. 104, 25-35 (2015)

[37] M.K. Rodrigues, B.R. Nunes, L.A.O. Rocha, E.D. dos Santos, L.A. Isoldi, Simulação Numérica de Trocador de Calor Solo-Ar Constituído por Formas Geométricas Complexas, Cereus 10, 12-25 (2018)

[38] A. Mathur, Priyam, S. Mathur, G.D. Agracial, J. Mathur, Comparative study of straight and spiral earth air tunnel heat exchanger system operated in cooling and heating modes, Renew. Energy 108, 474-487 (2017)

[39] S. Selamat, A. Miyara, K. Kariya, Numerical study of horizontal heat exchangers for design optimization, Renew. Energy 95, 561-573 (2016)

[40] H. Wei, D. Yang, Y. Guo, M. Chen, Coupling of earth-to-air heat exchangers and buoyancy for energy efficient ventilation of buildings considering dynamic thermal behavior and cooling/heating capacity, Energy 147, 587-602 (2018)

[41] D. Yang, Y. Guo, J. Zhang, Evaluation of the thermal performance of an earth-to-air heat exchanger (EAHE) in harmonic thermal environment, Energy Convers. Manag. 109, 184-194 (2016)

[42] M.K. Ghosal, G.N. Tiwari, D.K. Das, K.P. Pandey, Modeling and comparative thermal performance of ground air collector and earth heat exchanger for heating of greenhouse, Energy Build. 37, 613-621 (2005)

[43] V.M. Arcos Feria, Estudio experimental del desempeño térmico de un intercambiador de calor tierra aire en la ciudad de Chetumal, Quintana Roo. Master Thesis, Universidad de Quintana Roo, Quintana Roo, México, 2016

[44] H.P. Díaz-Hernández, E.V. Macias-Melo, K.M. AguilarCastro, I. Hernández-Pérez, J. Xamán, J. Serrano-Arellano, L.M. López-Manrique, Experimental study of an earth to air 
heat exchanger (EAHE) for warm humid climatic conditions. Renew. Energy in press (2018)

[45] C. Gauthier, M. Lacroix, H. Bernier, Numerical simulation of soil heat exchanger-storage systems for greenhouses, Solar Energy 60, 333-346 (1997)

[46] G. Mihalakakou, M. Santamauris, J.O. Lewis, D.N. Asimakopoulos, On the application of the energy balance equation to predict ground temperature profiles, Solar Energy 60, 181-190 (1997)

[47] V. Badescu, Simple and accurate model for the ground heat exchanger of a passive house, Renew. Energy 32, 845-855 (2007)

[48] S.V. Patankar, Numerical heat transfer and fluid flow, 1st ed., Hemisphere Series on Computational Methods in Mechanics and Thermal science, 1980
[49] J. Van Doormaal, G. Raithby, Enhancements of the SIMPLE method for predicting incompressible fluid flow, Numer.Heat Transfer 8, 147-163 (1984)

[50] J.M. House, C. Beckermann, T.F. Smith, Effect of a centered conducting body on natural convection heat transfer in an enclosure, Numer. Heat Transfer 18, 213-225 (1990)

[51] J.A. Díaz-Rodríguez, Los suelos lacustres de la ciudad de México. Revista Internacional de Desastres Naturales, Accidentes e Infraestructura Civil 6, 111-130 (2006)

[52] Instituto Nacional de Estadistica y Geografia, Prontuario de información geográfica municipal de los Estados Unidos Mexicanos. Mexico City. INEGI, 2009. https://www.inegi. org.mx

[53] CONAGUA, http://smn.cna.gob.mx/es/emas. México 2017

Cite this article as: M. Rodríguez-Vázquez, J. Xamán, Y. Chávez, I. Hernández-Pérez, E. Simá, Thermal potential of a geothermal earth-to-air heat exchanger in six climatic conditions of México, Mechanics \& Industry 21, 308 (2020) 